\title{
Consumer-centric factors for the implementation of smart meters in South Africa
}

\author{
Tonderai Muchenje (iD), Reinhardt A. Botha (iD \\ School of Information Communication Technology, Nelson Mandela University, Port Elizabeth, South Africa
}

\begin{abstract}
Smart meter implementation is still in its infancy in many African countries, including South Africa. This is evident from the fact that most research studies are either Eurocentric or American-centric. Hence, this research aimed to identify consumer-centric factors for planning considerations in implementation of smart meters in South Africa. We used various behavioural theoretical models found in literature to identify potential factors relevant to this study. Based on quantitatively gathered data $(n=705)$, a structural equation model (SEM) was used to evaluate the identified factors. This study found that only ten consumer-centric factors were significant to smart meter consumers. These factors include behavioural intention, attitude, trust in technology, social norms, facilitating conditions, perceived usefulness, perceived ease of use, privacy risk, monetary cost, and perceived value. In conclusion, the study shows that not all factors suggested within the European and American context are relevant for smart meter implementation within the South African context. Hence, results of this study hold some practical implications in assisting utility companies in identifying consumer-centric factors that are relevant to the South African population. Finally, consumer-centric factors can be used by policy makers and energy regulators as baseline factors for future pervasive technology acceptance studies.
\end{abstract}

Keywords: Smart meter, consumer-centric, perceived usefulness, perceived value, behavioural intention, structural equation model, trust in technology, privacy risk, facilitating conditions, social norms

Categories: • Human-centered computing $\sim$ Ubiquitous and mobile computing theory, concepts and paradigms

\section{Email:}

Tonderai Muchenje muchenjet@tut.ac.za (CORRESPONDING), Reinhardt A. Botha ReinhardtA.Botha@mandela.ac.za
Article history:

Received: 4 November 2020

Accepted: 25 November 2021

Available online: 19 December 2021

\section{INTRODUCTION}

The global demand for electric energy consumption. both for consumer and commercial use, has continued to increase rapidly owing to population and economic growth (Organisation for Economic Co-operation and Development, 2012). A sustainable future energy strategy is required to create innovative ways and systems that are relevant to transform the way

Muchenje, T. and Botha, R. A. (2021). Consumer-centric factors for the implementation of smart meters in South Africa. South African Computer Journal 33(2), 17-54. https://doi.org/10.18489/sacj.v33i2.909

Copyright (C) the author(s); published under a Creative Commons NonCommercial 4.0 License (CC BY-NC 4.0). $S A C J$ is a publication of the South African Institute of Computer Scientists and Information Technologists. ISSN 1015-7999 (print) ISSN 2313-7835 (online). 
electrical energy is produced, transmitted, distributed, and consumed. Otherwise, the access to electrical energy in the future will only be for the privileged, but unaffordable to the poor.

Currently, many countries worldwide are being forced to rethink their electricity infrastructure investment and energy generation, transmission, supply, and management in general (Eberhard et al., 2017), as a matter of urgency. Developed countries, such as the United States of America, and those in Europe, have taken initiatives to replace their ageing traditional electricity infrastructure with electricity grids commonly referred to as smart grids (J. Kranz et al., 2010; J. Kranz et al., 2015; J. J. Kranz \& Picot, 2011). It has been found that many parts of the traditional electricity grids in various countries are decades old, wearing out and failing to contain the increasing electricity demand, monitoring and control needed to support economic growth prospects (Bazilian et al., 2013; Manyika et al., 2013). Therefore, utility companies across the world are investing billions of dollars to upgrade and modernise electricity grids with smarter technologies, aiming to improve electricity usage efficiency, reliability, privacy, and security in the digital age (Camarinha-Matos, 2016; Ma et al., 2018). Although the implementation of smart meters, as part of the smart grid system, offers many benefits to both consumers and service providers (utility companies), it has been faced with wide resistance in many countries across the world.

Resistance to smart meter implementation is a reality in South Africa too. From consideration of the challenges mentioned above, several gaps can be identified that should be researched from an African customer perspective, because factors impacting smart meter adoption in Africa are potentially different from those in both America and Europe (J. Kranz et al., 2010; J. Kranz et al., 2015; J. J. Kranz \& Picot, 2011). Therefore, this research study was delineated to focus only on the South African context.

In South Africa, there is a need to understand and explore planning considerations for smart meter implementation and it was this need that became the major motivation for conducting this study. In relation to this, research is needed to support the development of a consumer-focused predictive model and planning considerations in smart meter implementation of planning projects, with specific reference to technology acceptance and use. Therefore, the need to investigate the consumer-centric factors that facilitate high acceptance of smart meter implementation for planning within the South African context can be considered vital research.

The paper first provides a background to the study on smart meters, discussing smart meter adoption in the rest of the world, highlighting the role of customer-centric factors. Subsequently, a justification for using the technology acceptance model as the foundational research model for this research is discussed. This is followed by a discussion of the supplementary models and development of the research model, as well as the theoretical underpinnings that the study. The discussion of the research methods is followed by hypothesis development, model testing and the presentation of the empirical results. The research paper concludes with a discussion of the theoretical implications. 


\section{BACKGROUND}

Energy is becoming the oxygen and lifeblood of the mass industrialized world and is a critical resource for fostering growth in emerging economies (World Economic Forum, 2012). The global demand for and consumption of energy, including electricity, is growing faster than its generation and supply capacity. To generate electricity at a capacity that can meet both residential and industrial demands, while keeping pace with economic growth and climate change requires striking a balance that is difficult to maintain (Wunderlich et al., 2012). Unfortunately, for many decades, electricity infrastructure has not changed much. Most components of the traditional electricity grid used in various countries are decades old and, consequently, are wearing out and failing to meet the increasing demand to supply electricity as well as control and monitor its consumption (Barrett et al., 2013; Manyika et al., 2013). Therefore, utility companies across the world are investing billions of dollars into upgrading and modernizing their electricity grid infrastructure with smarter technologies to improve its efficiency, reliability, privacy, and security, and launching them into the digital age (Bargh \& McKenna, 2004).

Incorporating smart meters (Wang et al., 2019) into the traditional electricity grid has become inevitable for countries that are pursuing sustainable development and energy efficiency (Zamrudi et al., 2019). Smart meters provide monitoring and control capabilities to the smart grid (Dileep, 2019). Consumers can remotely manage their energy consumption, while utility companies can manage and control the electricity supply, billing, and the monitoring of this finite resource (Zamrudi et al., 2019). The building of smart grids is a driving force behind energy efficiency and economic growth (Han et al., 2017).

\subsection{What are smart meters?}

As part of the modernization of the electricity infrastructure, smart meters are currently being deployed in various countries, including South Africa. Smart grids utilizing smart meter technology will modernize existing grids with bidirectional communication and pervasive communication capabilities for the smart generation, distribution, management, and consumption of electricity (Guo et al., 2015). Atkins (2014) defines a smart meter as

an electric meter that measures energy consumption data over specified intervals, has two-way communications capability, stores metering data in registers, supports a variety of tariffs (e.g., time of use, inclined block, maximum demand, free basic electricity) which can be remotely updated, can switch attached loads on command and interfaces to data concentrators.

Smart meter technology simplifies the meter reading process for energy utilities and enables new services, flexible tariffs, and demand response programs in the context of the smart grid. As the electricity grid becomes "smarter", it gains many new data collection, communication, and information sharing capabilities related to energy usage, and the related technologies in turn introduce new challenges that were not associated with the traditional system. 


\subsection{Smart meter adoption in European countries and the USA}

Although smart meters have benefits for both utility providers and consumers, there is still some resistance to the adoption of this technology. This section identifies consumer-centric factors that have impacted smart meter adoption, with specific reference to the USA and Europe as pioneers.

\subsubsection{The USA}

Jay et al. (2019) found that people generally support smart meter installation in the United States of America. This study included participants from 17 states with high smart meter installation rates. The results showed that privacy concerns, experience with privacy violations, and optimism in regard to accepting new technologies have an impact on consumer support for smart meter installations. They further suggested that communication to the public regarding privacy and economic benefits need to be clear to enhance adoption. In addition, Jay et al. (2019) also pointed out that social norms and technology readiness factors have some impact on the level of support for smart meter installations. Based on the Ithaca, New York study by Bugden and Stedman (2018), familiarity and climate change risk perceptions are the two factors that have the greatest impact on the acceptance of smart meters. S. Zhou (2021) discovered that dynamic pricing had a small impact on smart meters' penetration compared to supportive policies that facilitate the implementation and use of smart meters.

\subsubsection{European countries}

In their study of 23 European countries, Faruqui et al. (2010) found that the quantification of environmental benefits, transparency, and financial rewards based on low flat tariffs were among the factors that were proposed to boost smart meter acceptance. Based on a Dutch use case, Cuijpers and Koops (2013) found that privacy was a major driver in the acceptance of smart meters. They discovered that electric energy consumption intrudes on the privacy of personal life; therefore, they proposed a careful balance between smart metering and privacy protection.

S. Zhou and Brown (2017) studied four European countries, namely Finland, Sweden, the Netherlands, and Germany. The success stories of rolling out smart meters in Finland and Sweden were mainly based on regulatory mandates, positive financial regulations for the distributed system operators (DSOs), and policies to enhance social acceptance. From their perspective, the proper functioning of DSOs is vital to smart meter acceptance, as they deal with all operations, including the installation of smart meter devices, accurate billing and reading, marketing, data security and protection, and the authorization of third-party access to customer data. In the Netherlands, rollout resistance was caused by privacy and data security concerns leading to low social acceptance. In Germany, privacy was a major concern that led to low acceptance.

McKenna et al. (2012) propose addressing consumer privacy concerns early on to avoid a delay in smart meter deployment in their United Kingdom research study. In addition, Rausser 
et al. (2018) also suggest that economic benefit through a reduction in the cost of smart meters and other related costs could also increase smart meter adoption.

In summary, the consumer-centric factors identified as enhancing smart meter acceptance in the USA were privacy concerns, experience with privacy violations, optimism in regard to accepting new technologies, familiarity, smart meter supportive policies and social norms, and climate change risk perceptions. The quantification of environmental benefits, transparency, financial rewards, regulatory mandates, positive financial regulations for the DSOs, privacy and data security concerns, economic benefits, and policies that enhance social acceptance were identified as such factors in European countries. Although privacy concerns, economic or financial rewards, and environmental benefits or climate risk perceptions were found to be common consumer-centric factors in both Europe and the USA, some country-specific factors were also identified. Familiarity, technology readiness, optimism in regard to accepting new technology and social norms and were specific to the USA, while regulatory mandates, financial regulations of the DSOs, and policies for social acceptance were found to have aided in smart meter implementations in Europe.

Since the level of smart meter installation in South Africa is in its infancy, most municipalities are still battling to get smart meters implemented and functioning to realize their benefits. This is evident in reported cases of incorrect billing and poor customer support. Therefore, this study needs to identify consumer-centric factors that can enhance smart meter acceptance in South Africa, as some of the factors outlined in the USA and Europe may not directly fit South Africa's geo-economic and political landscape.

\section{THEORETICAL FRAMEWORK: THE TECHNOLOGY ACCEPTANCE MODEL}

As the decision to accept and use a new technology depends on uncertain benefits and uncertain costs, understanding the factors affecting choice is vital for both technology innovators and policy makers in relation to future technology developments (World Economic Forum, 2016). Theories that predict how a user comes to accept and use a specific technology have been dealt with extensively in past research, as is evident in Table 1 . These theories suggest a number of constructs that influence a user's decisions about how and when they will use a new technology. TAM was chosen based on its focus on user acceptance and use (Table 1) and an extension of the TRA and TPB (Miltgen et al., 2013a). As for the UTAUT, it focuses on organisational technology acceptance (Venkatesh et al., 2012). 
Table 1: Technology and user acceptance theories

\begin{tabular}{|c|c|c|c|}
\hline Model & Constructs & Definitions & Source \\
\hline $\begin{array}{l}\text { Privacy } \\
\text { calculus } \\
\text { theory }\end{array}$ & $\begin{array}{l}\text { Perceived ease of use } \\
\text { Perceived usefulness } \\
\text { Relevant social groups } \\
\text { Institutional privacy } \\
\text { assurance } \\
\text { Perceived privacy } \\
\text { risks }\end{array}$ & $\begin{array}{l}\text { The Privacy Calculus Theory argues that a } \\
\text { consumer's ability to take risks (disclosure of } \\
\text { personal information) is influenced by the } \\
\text { consumer's perception of benefits against risks } \\
\text { (the calculus). }\end{array}$ & $\begin{array}{l}\text { Morosan and } \\
\text { DeFranco (2015) } \\
\text { Sun et al. (2015) } \\
\text { James et al. (2015) } \\
\text { Keith et al. (2013) } \\
\text { Dinev et al. (2006) }\end{array}$ \\
\hline $\begin{array}{l}\text { Theory of } \\
\text { Reasoned } \\
\text { Action }\end{array}$ & $\begin{array}{l}\text { Attitude } \\
\text { Subject norms }\end{array}$ & $\begin{array}{l}\text { The Theory of Reasoned Action suggests that a } \\
\text { person's behaviour is determined by a person's } \\
\text { intention to perform the behaviour and that this } \\
\text { intention is, in turn, a function of a person's } \\
\text { attitude toward the behaviour and a person's } \\
\text { subjective norm. }\end{array}$ & $\begin{array}{l}\text { Fishbein and Ajzen } \\
(1975) \\
\text { Vallerand et al. } \\
\text { (1992) } \\
\text { Rehman et al. (2003) }\end{array}$ \\
\hline $\begin{array}{l}\text { Theory of } \\
\text { Planned } \\
\text { Behaviour }\end{array}$ & $\begin{array}{l}\text { Attitude } \\
\text { Subject norms } \\
\text { Perceived behavioural } \\
\text { control }\end{array}$ & $\begin{array}{l}\text { An individual's behaviour is driven by behaviour } \\
\text { intentions, where behaviour intentions are a } \\
\text { function of three determinants: an individual's } \\
\text { attitude toward behaviour, subjective norms and } \\
\text { perceived behavioural control. The concept was } \\
\text { proposed by Ajzen in } 1991 \text { to improve on the } \\
\text { predictive power of the theory of reasoned action } \\
\text { by including perceived behavioural control. }\end{array}$ & $\begin{array}{l}\text { Rehman et al. (2003) } \\
\text { Cheon et al. (2012) } \\
\text { L. E. Davis et al. } \\
\text { (2002) } \\
\text { Bamberg et al. (2003) } \\
\text { Notani (1998) } \\
\text { Lynne et al. (1995) } \\
\text { Ajzen (1985) }\end{array}$ \\
\hline $\begin{array}{l}\text { Technology } \\
\text { Accep- } \\
\text { tance } \\
\text { Model }\end{array}$ & $\begin{array}{l}\text { Perceived usefulness } \\
\text { External variables } \\
\text { Perceived ease of use } \\
\text { Attitude towards be- } \\
\text { havioural intention }\end{array}$ & $\begin{array}{l}\text { The Technology Acceptance Model (TAM) is an in- } \\
\text { formation systems theory that models how users } \\
\text { come to accept and use a technology. }\end{array}$ & $\begin{array}{l}\text { Ajzen (1991) } \\
\text { Sánchez-Prieto et al. } \\
\text { (2015) } \\
\text { Miltgen et al. (2013a) }\end{array}$ \\
\hline $\begin{array}{l}\text { Diffusion } \\
\text { of } \\
\text { Innovation } \\
\text { Theory }\end{array}$ & $\begin{array}{l}\text { Relative advantage } \\
\text { Compatibility } \\
\text { Trialability } \\
\text { Observability } \\
\text { Complexity }\end{array}$ & $\begin{array}{l}\text { Diffusion research centres on the conditions } \\
\text { which increase or decrease the likelihood that } \\
\text { members of a given social system will adopt a } \\
\text { new idea, product or practice. }\end{array}$ & $\begin{array}{l}\text { F. D. Davis et al. } \\
\text { (1989) } \\
\text { Srivastava and } \\
\text { Moreland (2012) }\end{array}$ \\
\hline $\begin{array}{l}\text { Unified } \\
\text { Theory of } \\
\text { Accep- } \\
\text { tance and } \\
\text { Use of } \\
\text { Technol- } \\
\text { ogy }\end{array}$ & $\begin{array}{l}\text { Performance } \\
\text { expectancy } \\
\text { Effort expectancy: } \\
\text { The ease of use of the } \\
\text { technologies } \\
\text { Social factors } \\
\text { Facilitating conditions } \\
\text { Attitude } \\
\text { Behavioural } \\
\text { intentions }\end{array}$ & $\begin{array}{l}\text { The Unified Theory of Acceptance and Use of } \\
\text { Technology model aims to explain user intentions } \\
\text { to use an information system and subsequent } \\
\text { usage behaviour. }\end{array}$ & $\begin{array}{l}\text { Miltgen et al. (2013b) } \\
\text { Thomas et al. (2013) } \\
\text { Martins et al. (2014) } \\
\text { Venkatesh et al. } \\
\text { (2012) }\end{array}$ \\
\hline
\end{tabular}


Based on the literature review, TAM has been useful in studying the intent to accept new technologies in a variety of contexts in Table 2. TAM is useful in different situations to explain information system acceptance and use. TAM has also been shown to be reliable and valid in many studies (Lai, 2017); thus, it provides a useful starting point. Therefore, TAM was used as a foundational framework for this study, contributing extensively to the research model. Though the TAM is a widely used model for studies about technology acceptance and use, it has some weaknesses in that it overlooks certain individual factors that could influence the choice to accept or reject a technology. Such individual factors can either provide additional variables to the TAM or provide an integrative view of the variables needed to explain or predict technology acceptance (S. Chen et al., 2011). Micheni et al. (2013) posit that, although the TAM provides valuable insights that focus mainly on the determinants of intention, it does not predict how perceptions are formed and how they can be manipulated to enhance user acceptance and increase technology usage. In this study, the motives that drive the acceptance of smart meter technology, in reality, may introduce additional significant constructs such as trust (Gefen et al., 2003; Wu \& Chen, 2005), privacy concerns (Keith et al., 2013; T. Zhou, 2011), price value, and facilitating conditions (Venkatesh et al., 2012). These additional constructs cannot be explained or explicitly dealt with in the TAM or individually in other acceptance models.

As has been suggested above, TAM could not adequately cover all the consumer-centric factors that are relevant for smart meters; therefore, an extended TAM was developed for smart meters for this study. The next section provides an extended TAM for smart meters.

\section{EXTENDED TECHNOLOGY MODEL FOR SMART METERS}

Through an extensive review of the literature, TAM was identified as the seminal model for modelling behavioural intention to accept and use smart meters. In applying the TAM to this study, behavioural intention was defined as a consumer's indication of his/her readiness to accept and use smart meter technology (Miltgen et al., 2013a). The TAM suggests that the intention towards a behaviour can be predicted from perceived ease of use and perceived usefulness that is governed by a consumer's attitude towards using a technology, such as a smart meter, as is the case in this study.

\subsubsection{Attitude}

Attitude is expected to have a direct positive relationship with behavioural intentions to accept smart meter technology. According to Fishbein and Ajzen (1975), attitude is defined as the degree to which the performance of the behaviour is positively or negatively valued by an individual. In support, Miltgen et al. (2013a) suggest that the attitude towards performing a behaviour is jointly influenced by perceived usefulness and perceived ease of use. This joint relationship confirmed by Miltgen et al. (2013a), is widely accepted and verified by several past studies. As hypothesised by the TAM (Miltgen et al., 2013a), if a consumer has a positive 
Table 2: Past research studies that have used the Technology Acceptance Model

\begin{tabular}{|c|c|c|}
\hline Application domain & Research study context & Source \\
\hline \multirow[t]{4}{*}{ Banking } & Customer acceptance of internet banking & Maduku (2013) \\
\hline & Adoption of internet banking & Lee (2009) \\
\hline & Adoption of Mobile Money Services & Micheni et al. (2013) \\
\hline & Mobile banking & Gu et al. (2009) \\
\hline \multirow[t]{3}{*}{ Government services } & Electronic toll collection service & C. Chen et al. (2007) \\
\hline & Hospital information system acceptance & Lu and Gustafson (1994) \\
\hline & $\begin{array}{l}\text { End users' reactions to health information } \\
\text { technology }\end{array}$ & Holden and Karsh (2010) \\
\hline \multirow[t]{4}{*}{ Commerce } & Online trading & Gefen et al. (2003) \\
\hline & Consumer acceptance of online auctions & Holden and Karsh (2010) \\
\hline & E-commerce acceptance & $\begin{array}{l}\text { Roca et al. (2009) and Stern et al. } \\
(2008)\end{array}$ \\
\hline & User acceptance of world-wide web & Gefen and Straub (2000) \\
\hline \multirow[t]{3}{*}{ Education } & Examining faculty use of Online Learning Systems & Moon and Kim (2001) \\
\hline & $\begin{array}{l}\text { Understanding academics' behavioural intention } \\
\text { to use Learning Management Systems }\end{array}$ & Fathema et al. (2015) \\
\hline & E-learning attitudes & Alharbi and Drew (2014) \\
\hline \multirow[t]{2}{*}{ Privacy and security } & Biometric applications & Holden and Karsh (2010) \\
\hline & $\begin{array}{l}\text { User acceptance of radio-frequency identification } \\
\text { (RFID) }\end{array}$ & Park (2009) \\
\hline \multirow[t]{2}{*}{$\begin{array}{l}\text { Geography and } \\
\text { environmental service }\end{array}$} & $\begin{array}{l}\text { Consumer acceptance of location-based services in } \\
\text { the retail environment }\end{array}$ & T. Zhou (2011) \\
\hline & $\begin{array}{l}\text { Investigating the impact of privacy concerns on } \\
\text { user adoption of location-based services }\end{array}$ & Muller-Seitz et al. (2009) \\
\hline \multirow[t]{3}{*}{ General application } & User acceptance of interface agents in daily work & Uitz and Koitz (2013) \\
\hline & Understanding of self-service technologies & Serenko et al. (2007) \\
\hline & Perception about the use of electronic mail & S. Chen et al. (2009) \\
\hline
\end{tabular}

attitude towards using smart meter technology, he or she is more likely to have an intention to use a smart meter. Therefore, the following relationship was tested:

H1: Consumers with a positive attitude towards smart meter technology will have a positive behavioural intention to use smart meter technology.

Though the TAM provided the base on which the structural theory of the proposed research model was established for this study, it has certain weaknesses in overlooking other individual constructs that could influence the choice to accept or reject a technology (S. Chen et al., 2011). Consequently, other individual factors were included to provide the interrogative view needed to explain or predict technology acceptance as it relates to this study about smart meter technology implementation. 


\subsubsection{Perceived usefulness}

Perceived usefulness is expected to influence both attitude and behavioural intention positively to accept and use smart meter technology. Perceived usefulness is defined as the prospective user's subjective probability that using a specific application will increase his or her job performance within an organisational context (Miltgen et al., 2013a). In the context of this study, the intention to accept smart meter technology is expected to be linked to benefits that can be derived from using it. Based on previous studies, perceived usefulness has been found to be a strong determining factor in predicting behavioural intention (Miltgen et al., 2013a; Tan et al., 2012; Venkatesh et al., 2012). Similar to the TAM hypothesis, perceived usefulness is most likely to encourage a consumer to derive more benefits from managing electricity using a smart meter. Therefore, the following hypothesis was tested:

H2: Consumers with higher perceived usefulness will have a positive behavioural intention to use smart meter technology.

Apart from perceived usefulness influencing behavioural intentions, Miltgen et al. (2013a) note that there is empirical evidence that shows perceived usefulness to have an influence on attitude towards using a technology. Taking the findings of Miltgen et al. (2013a) into consideration, this study posits that those benefits derived from using a smart meter will impact positively on consumer perception of how favourable smart meter technologies are. Therefore, the following hypothesis was tested:

H3: Consumers with higher perceived usefulness will have a positive attitude towards the use of smart meter technology.

\subsubsection{Ease of use}

In this study, perceived ease of use is expected to have a positive influence on both perceived usefulness and attitude. Perceived ease of use is defined as the degree to which a user perceives that the effort required to use a particular technology will be minimal (Miltgen et al., 2013a; Ten Kate et al., 2010). The structural model of this study predicted that the ease-of-use construct has a direct relationship with both perceived ease of use and attitude. This notion is based on prior studies (Miltgen et al., 2013a; Venkatesh et al., 2012). For the purposes of this study, it is postulated that if a consumer believes that using a smart meter is effortless, they are more likely to exhaust all the benefits that can be derived from using it and, when realising the maximum benefits, they will have a positive attitude towards using the system. Considering the findings of prior studies, if a consumer finds it easy and effortless to use a smart meter, he or she is more likely to use it and have a positive attitude towards smart meter technology (Ma et al., 2018). Therefore, the following hypothesis is tested:

H4: Consumers with higher ease of use will have a significantly positive relationship with perceived usefulness towards the use of smart meter technology. 
H5: Consumers with higher ease of use will be significantly positive towards the attitude to use smart meter technology.

\subsection{Technology Acceptance Model integrated constructs within smart meters}

Since the TAM was found to be inadequate-and did not provide all the relevant factors that might influence customer behaviour-supplementary factors that might have relevance in predicting the behavioural intention to use smart meters were added to the model developed for this study. Sections 4.1.1 to 4.1.4 consider these supplementary factors and the proposed hypotheses that were investigated in relation to these factors.

\subsubsection{Perceived value}

Perceived value is expected to have a positive and direct influence on behavioural intention to accept smart meter technology. Perceived value can be defined as a consumer's overall subjective evaluation of the utility of a product or service mainly based on the trade-off between perceived benefits (utility) and perceived sacrifices or cost (Hazen et al., 2015; Zeithaml, 1988). As found in other studies, individuals are more likely to adopt a new technology if the perceived benefits outweigh the cost of acquiring or using the system (Sun et al., 2015; van Ittersum et al., 2006; Xiong, 2013). Perceived value can be expressed as an equation:

$$
\text { Perceived value }=\frac{\text { Benefits (functional benefits }+ \text { emotional benefits) }}{\text { Costs (monetary costs }+ \text { time costs }+ \text { energy costs }+ \text { privacy risks) }}
$$

In agreement, Xiong (2013) suggest that consumers tend to value mobile banking more if the benefits of using it are greater than the monetary cost and privacy risk to be incurred. Therefore, if consumers believe that using smart meter technology is valuable, they are more likely, in turn, to have positive intentions towards accepting and using it. The following hypotheses related to perceived value were tested:

H6: Customers with higher monetary cost will have a negative effect on the perceived value of using smart meter technology.

H7: Consumers with higher privacy/perceived risk will have a negative influence on the perceived value of smart meter technology.

H8: Consumers with higher perceived value will have a positive behavioural intention to use smart meter technology.

H9: Monetary cost positively affects the perceived usefulness of using smart meter technology.

H10: Perceived usefulness will have a positive effect on the perceived value of using smart meter technology. 


\subsubsection{Facilitating conditions}

Facilitating conditions are expected to have a positive influence on both ease of use and behavioural intentions to accept and use smart meters. According to Ghalandari (2012) and Venkatesh et al. (2012), facilitating conditions can be defined as the extent to which consumers perceive that the resources and support required to perform a behaviour are available. In the context of this study, resources and support could be in the form of awareness campaigns, educational workshops and demonstration sessions on how to use the smart meters in order to enhance effortless use of the system. As suggested in some studies, facilitating conditions can influence intention to accept a technology both directly and indirectly through attitude (Ajzen, 1991; Ghalandari, 2012; Moon \& Kim, 2001; Venkatesh et al., 2012). In contrast, other studies suggest that facilitating conditions are found to influence ease of use as compared to their influence on attitude (Moon \& Kim, 2001; Venkatesh et al., 2012). Hence, if a consumer believes that facilitating conditions make it easy to operate a smart meter without much effort, he or she is likely to have the intention to accept smart meter technology. Therefore, the following two hypotheses were tested:

H11: Consumers with high levels of facilitating conditions will have a significant relationship with ease of use.

H12: Consumers with high levels of facilitating conditions would have a positive behavioural intention to use smart meter technology.

\subsubsection{Trust in technology}

Trust in technology is another of the additional independent constructs incorporated into the model used in this study. Trust in technology is expected to have a positive influence on both attitude and behavioural intention to accept and use smart meter technology. Prior research has shown that trust has been a critical factor in predicting the intention to accept and use technology (Dinev \& Hart, 2006; Gefen et al., 2003; Joubert \& van Belle, 2013; T. Zhou, 2011). In general, Mayer et al. (1995) define trust as the willingness of a user to be vulnerable to the actions of another party based on the expectation that the other party will perform a particular action important to the truster, irrespective of the ability to monitor or control that other party. Based on the findings of other studies, trust becomes a key driver for intention and use of online systems owing to its relevance in dealing with uncertainty and risk vulnerability transactions (Doney \& Cannon, 1997; Gefen et al., 2003; Thatcher et al., n.d.). McKnight et al. (2002) further suggest that institutionally based trust (referred to as trust in technology) also has an impact on attitude toward accepting and using a particular technology. Hence, if a consumer perceives that the smart meter environment, including supporting structures and regulations, makes the environment feel safe, he or she is likely to have a positive attitude towards the system, which in turn will lead to an intention to accept and use smart meter technology and a belief and trust in the technology. Therefore, the following three hypotheses were tested: 
H13: Consumers with higher trust in technology will have a positive perceived usefulness towards the use of smart meter technology.

H14: Consumers with higher trust in technology will have a positive attitude toward the use of smart meter technology.

H15: Consumers with higher trust in smart meter technology will have a significant positive relationship with behavioural intention to use smart meter technology.

\subsubsection{Social norms}

Social norms are another independent construct added to the modified TAM, which is expected to relate positively to behavioural intention to accept smart meter technology. The social norms construct is described as social pressure placed on the consumer to perform or not to perform a behaviour (Cuijpers \& Koops, 2013; Fishbein \& Ajzen, 1975). While most studies concur, that social norms have an influence on behavioural intentions (Beldad \& Hegner, 2018), some TPB studies emphasise that the assertion holds when technology acceptance is mandatory. In this study, the influence of friends, family, colleagues, and other social groups have a positive impact on the consumer's intention to accept smart meter technology. Hence, the following hypothesis was tested:

H16: Consumers with higher social norms will have a positive behavioural intention to use smart meter technology.

After the specification of the research model structural theory, all the constructs used were classified into two groups, namely exogenous constructs and endogenous constructs. This was done as part of the process of developing the structural model. The exogenous and endogenous constructs are both represented in the proposed research model below.

\subsection{Proposed research model}

In this study, a path diagram was developed of the proposed structural model to represent the structural theory. Facilitating conditions, social norms, monetary cost and privacy risk were classified as exogenous constructs. As suggested by Hair et al. (2010), exogenous constructs are independent constructs that are used to predict other constructs in the structural model; hence, they are not hypotheses that can be tested on them. Therefore, as per the path diagram in Figure 1, they are not single arrows that are supposed to enter them; rather, the arrows that came from them enter endogenous constructs. Hair et al. (2010), Hair et al. (2017) refer to endogenous constructs as the constructs in the structural model that are determined by other constructs (exogenous constructs). They further emphasise that endogenous constructs are usually the result of the hypotheses to be tested and verified. Therefore, in order to test the proposed structural relationships in the proposed structural model, structural equation modelling was used to test all 16 hypotheses. Figure 1 shows all the hypotheses that were tested in the structural model. 


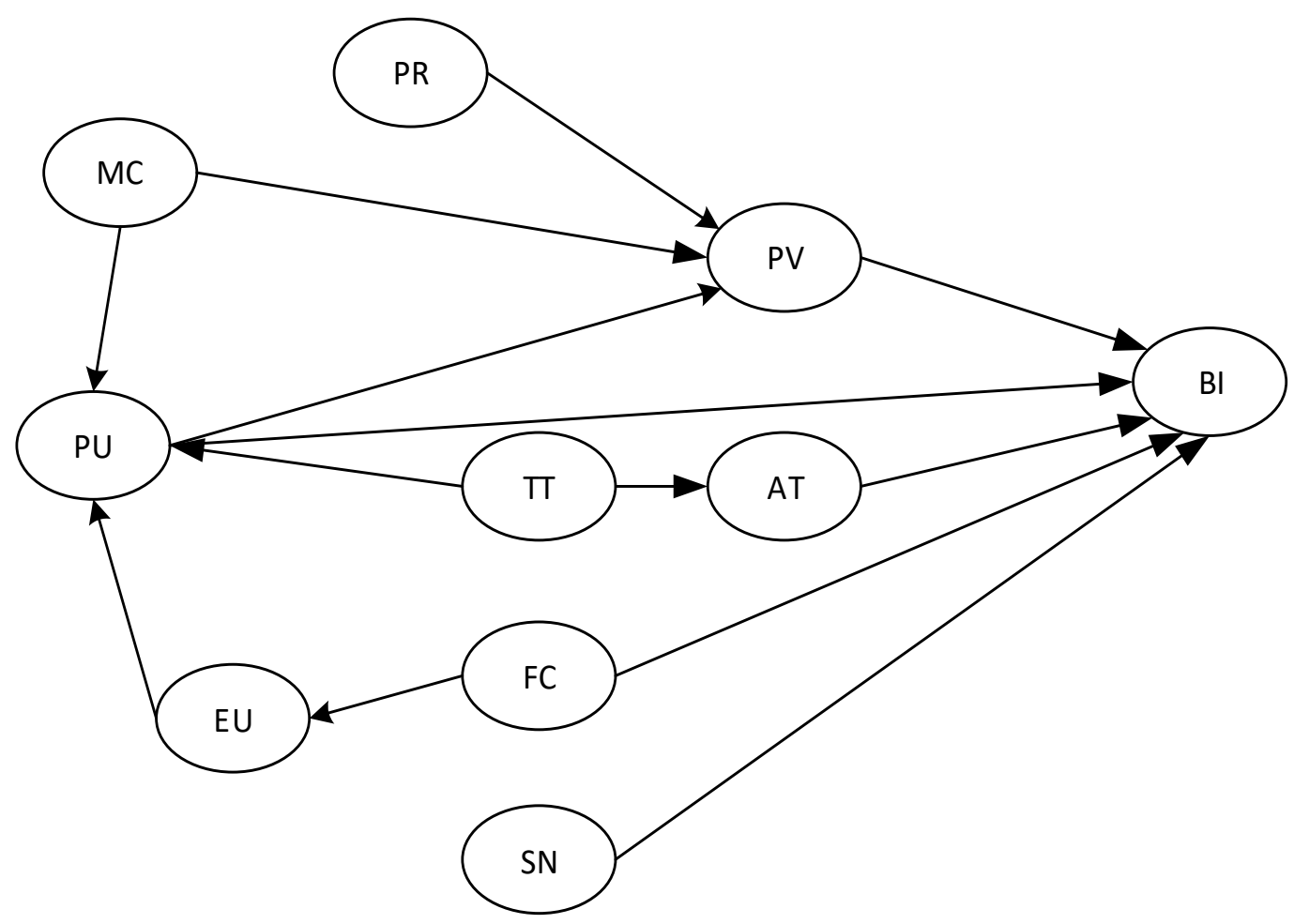

Figure 1: Proposed research structural model

BI: Behavioural intention, AT: Attitude, PV: Perceived value, PR: Privacy risk, MC: Monetary cost, PU: Perceived usefulness, EU: Ease of use, TT: Trust in technology, FC: Facilitating conditions,

SN: Social norms

\section{DATA COLLECTION METHODOLOGY}

The quantitative data for this research study were collected in two ways. Online and manual data collection methods were employed. The online data collections mainly targeted those we could not have physical access to in various municipalities and towns, while the manual data collection was focused on those where we had easy physical access, like residents in Pretoria and Johannesburg. The two-research assistant chosen were trained and inducted in terms of the research data collection procedures in order to enhance data collection consistency. Both manual and online data collection was only targeted at those within South African borders.

The survey of smart and non-smart meter consumers was chosen to test the predicted constructs and their relationships within the model. Since smart meter technology implementation is still in its infancy in South Africa (Smart Energy International, 2019), the questionnaire included a section with an infographic of the smart meter display, and a brief description and illustration of smart meter technology to the participants in order to establish a common understanding among all respondents. 


\section{PARTICIPANTS AND TARGETED SAMPLE}

The survey sample consisted of residential consumers within South Africa. Consumers were targeted in municipalities that have started implementing smart meters, such as City of Tshwane, City of Johannesburg, City of Cape Town, and City of Ekurhuleni. As such, both smart meter and non-smart meter users were included. Participants were approached based on being employed and thus likely to be responsible or co-responsible for energy decisions in their household. South Africa was chosen to be a test bed for the investigation in order to identify the consumer-centric factors that might be applicable in an African context since most previous research studies were either Eurocentric or American-centric (Smart Energy International, 2019).

Overall, 768 respondents completed the questionnaire. Thereafter, the gathered questionnaires were screened and those not completely filled were eliminated from the final analysis using the list-wise missing data handling. After removing 63 questionnaires from the 768, the result in response rate was $88.1 \%$. The final sample size was 705 respondents from the target South African electricity population at the time of study of 31 million, which was considered acceptable, according to Hair et al. (2010) and Krejcie and Morgan (1970). The ages of survey participants ranged from $18-50$ and above, with 54.15\% males and $45.84 \%$ females. For more details, the characteristics of the targeted sample demographics are presented in Table 3.

\section{MEASUREMENT DEVELOPMENT}

Although TAM is widely used for researching technology acceptance and use, its applicability was found to be inadequate in explaining customer-centric factors in smart metering. The questionnaire was developed to measure the constructs in the research model. The constructs in the research model were trust in technology, perceived usefulness, perceived ease of use, perceived privacy risk, monetary cost, perceived value, attitude, facilitating conditions, social norms, and behavioural intention.

The behavioural intention, attitude, perceived usefulness, and perceived ease of use were measured using an adapted model from Belanche et al. (2012), Kaushik et al. (2015), Venkatesh et al. (2012), and Xu et al. (2011), while some were self-developed in the context of smart metering. The items to measure the facilitating conditions construct were adapted from Martins et al. (2014) and Venkatesh et al. (2012). The perceived value items were adapted from Agarwal et al. (2007) and Kim et al. (2009). The perceived privacy risk was adapted from Krasnova and Veltri (2010), Taneja et al. (2014), and Venkatesh et al. (2012), and the items for trust in technology were modified from Belanche et al. (2012) and Thatcher et al. (n.d.). Within some constructs, items were self-developed and reworded in the smart meter context of the study. All the constructs were measured using a 7-point Likert scale, with one (1) meaning 'strongly agree' and seven (7) meaning 'strongly disagree'. For more detail on all the constructs and their measurement items used in the research model, see the derivation of construct items in Appendix A and the final constructs in Appendix B. 
Table 3: Descriptive statistics

\begin{tabular}{|c|c|c|}
\hline Gender & Frequency & Percentage \\
\hline Male & 358 & 54.16 \\
\hline Female & 303 & 45.84 \\
\hline Missing data & 44 & 24 \\
\hline \multicolumn{3}{|l|}{ Age } \\
\hline $18-25$ & 100 & 15.27 \\
\hline 26-35 & 195 & 29.77 \\
\hline $36-45$ & 181 & 27.63 \\
\hline $46-50$ & 96 & 14.66 \\
\hline$>50$ & 83 & 12.67 \\
\hline Missing data & 50 & 7.00 \\
\hline \multicolumn{3}{|l|}{ Education level } \\
\hline No schooling & 5 & 0.76 \\
\hline Has some schooling & 21 & 3.20 \\
\hline Matriculated & 84 & 12.80 \\
\hline Certificate & 76 & 11.76 \\
\hline Diploma & 164 & 2500 \\
\hline Undergraduate (with Honours) & 203 & 30.95 \\
\hline Masters and Doctorates & 103 & 15.70 \\
\hline Missing data & 49 & 6.95 \\
\hline \multicolumn{3}{|l|}{ Average annual income } \\
\hline Less than R150 000 & 263 & 41.55 \\
\hline R150 000-R299 000 & 143 & 22.59 \\
\hline R300 000-R449 000 & 92 & 14.33 \\
\hline R450 000-R599 000 & 57 & 9.00 \\
\hline R600 000-R749 000 & 34 & 5.73 \\
\hline Above R900 000 & 23 & 3.63 \\
\hline Missing data & 103 & 10.21 \\
\hline \multicolumn{3}{|l|}{ Smart users descriptive } \\
\hline Current users & 287 & 44.50 \\
\hline Non-users & 358 & 55.50 \\
\hline Missing data & 60 & 8.50 \\
\hline \multicolumn{3}{|l|}{ Smart meter service provider } \\
\hline Tshwane Metropolitan & 363 & 55.42 \\
\hline Eskom & 89 & 13.59 \\
\hline Others & 61 & 9.31 \\
\hline Johannesburg Metropolitan & 49 & 7.48 \\
\hline Private companies & 41 & 6.26 \\
\hline Ekurhuleni Metropolitan & 26 & 3.97 \\
\hline Non-Metropolitan & 10 & 1.53 \\
\hline Cape Town Metropolitan & 9 & 1.37 \\
\hline eThekwini Metropolitan & 7 & 1.07 \\
\hline Missing data & 50 & 7.09 \\
\hline Total & 705 & $100 \%$ \\
\hline
\end{tabular}


In addition to the construct measurements for the research model, smart user demographics information was also collected, mainly to gather information about the target sample population. Before the final data collection, three-stage pre-testing (15, 73 and 55 participants) of the questionnaire was conducted to address misunderstandings regarding some statements, words, ambiguity, flow, and the overall layout of the questionnaire. Some adjustments were made to the construct and construct items, which did not achieve recommended levels for items internal consistency, construct reliability, and validity (Hair et al., 2010).

Table 4: Recommended goodness-of-fit indices for the research model (Hair et al., 2010; Hair et al., 2017)

\begin{tabular}{llll} 
Name of category & & Index name & $\begin{array}{l}\text { Acceptable } \\
\text { level }\end{array}$ \\
\hline Chi Square $\left(X^{2}\right)$ & $X^{2}$ & Discrepancy Chi Square & n/a \\
\hline Degrees of freedom & $D f$ & Degrees of Freedom & n/a \\
\hline Absolute fit & RMSEA & Root mean squared error of approximation & n/a \\
& GFI & Goodness of fit & $>0.9$ \\
& $90 \%$ CI of & 90\% confidence interval of root mean & $0.03->0.08$ \\
& RMSEA & squared error of approximation & \\
& RMR & Root mean residual & $<0.05$ \\
& SRMR & Standardised root mean residual & $<0.05$ \\
\hline Incremental fit & Normed $X^{2}$ & Normed Chi Square & $<2.0-<5.0$ \\
& NNI & Normed fit index & $>0.90$ \\
& CFI & Non-normed fit index & $>0.90$ \\
& TLI & Comparative fit index & $>0.90$ \\
\hline Parsimonious fit in- & PNFI & Tucker-Lewis index & $>0.95$ \\
\hline dices & Parsimonious normed fit index & $>0.95$ \\
& AGFI & Adjusted goodness-of-fit index & $>0.95$ \\
\hline
\end{tabular}


Table 5: Goodness of fit for the proposed smart meter measurement model validity (Hair et al., 2010; Hair et al., 2017)

\begin{tabular}{lllll}
$\begin{array}{l}\text { Name of } \\
\text { category }\end{array}$ & Index & $\begin{array}{l}\text { Recommended } \\
\text { level }\end{array}$ & $\begin{array}{l}\text { Measurement } \\
\text { model values }\end{array}$ & Comments \\
\hline Chi Square $\left(X^{2}\right)$ & $X^{2}$ & n/a & 2658.66 & \\
\hline $\begin{array}{l}\text { Degree of free- } \\
\text { dom }\end{array}$ & $D f$ & n/a & 944 & \\
\hline Absolute fit & $\begin{array}{l}\text { RMSEA } \\
\text { 90\% confidence } \\
\text { interval RMSEA }\end{array}$ & $\begin{array}{l}<0.06 \text { or } 0.07 \\
\text { SRMR }\end{array}$ & $<0.05$ & $\begin{array}{l}\text { Achieved level } \\
\text { Achieved level }\end{array}$ \\
& $\begin{array}{l}<0.05 \\
\text { Normed } X^{2}\end{array}$ & $<2.0$ and $<5.0$ & $0.04-0.05$ & 2.8 \\
\hline Incremental fit & CFI & $>0.90$ & $>0.97$ & $\begin{array}{l}\text { Achieved level } \\
\text { Achieved level }\end{array}$ \\
& TLI & $>0.95$ & $>0.96$ & $\begin{array}{l}\text { Achieved level } \\
\text { Achieved level }\end{array}$ \\
\hline
\end{tabular}

Table 6: Construct correlation matrix

EU: Ease of use, FC: Facilitating conditions, PU: Perceived usefulness, PR: Privacy risk, PV: Perceived value, TT: Trust in technology, SN: Social norms, AT: Attitude, BI: Behavioural intention.

Discriminant validity: AVE values $>$ Squared correlations.

Note: Values below the diagonal are correlation estimates among constructs, the diagonal element is constructed variance, and values above the diagonal are squared correlations.

\begin{tabular}{lrrrrrrrrrr}
\hline Construct & EU & FC & PU & MC & PR & PV & TT & SN & AT & BI \\
\hline EU & 1.000 & & & & & & & & & \\
FC & 0.731 & 1.000 & & & & & & & & \\
PU & 0.675 & 0.660 & 1.000 & & & & & & & \\
MC & 0.025 & 0.028 & 0.043 & 1.000 & & & & & & \\
PR & 0.141 & 0.143 & 0.184 & 0.200 & 1.000 & & & & & \\
PV & 0.505 & 0.466 & 0.549 & 0.015 & 0.208 & 1.000 & & & & \\
TT & 0.550 & 0.563 & 0.575 & 0.017 & 0.179 & 0.746 & 1.000 & & & \\
SN & 0.387 & 0.390 & 0.433 & 0.017 & 0.190 & 0.501 & 0.620 & 1.000 & & \\
AT & 0.530 & 0.509 & 0.588 & 0.013 & 0.160 & 0.683 & 0.769 & 0.620 & 1.000 & \\
BI & 0.556 & 0.524 & 0.598 & 0.007 & 0.136 & 0.705 & 0.778 & 0.615 & 0.901 & 1.000 \\
\hline
\end{tabular}


Table 7: Summary of the standardised factor loadings, reliability and average extracted variance Note: If the factor loading $>=0.7$, AVE cut-off values $>0.5$ and Cronbach alpha $>=0.7$ then the constructs show convergent validity.

\begin{tabular}{|c|c|c|c|}
\hline Construct & Factor loading & Cronbach alpha & Average extracted variance \\
\hline \multirow[t]{4}{*}{ Ease of use } & 0.904 & \multirow{4}{*}{0.944} & \multirow{4}{*}{0.811} \\
\hline & 0.944 & & \\
\hline & 0.904 & & \\
\hline & 0.848 & & \\
\hline \multirow[t]{4}{*}{ Facilitating conditions } & 0.904 & \multirow{4}{*}{0.961} & \multirow{4}{*}{0.864} \\
\hline & 0.944 & & \\
\hline & 0.904 & & \\
\hline & 0.848 & & \\
\hline \multirow[t]{4}{*}{ Perceived usefulness } & 0.904 & \multirow{4}{*}{0.972} & \multirow{4}{*}{0.896} \\
\hline & 0.944 & & \\
\hline & 0.904 & & \\
\hline & 0.848 & & \\
\hline \multirow[t]{4}{*}{ Monetary cost } & 0.904 & \multirow{4}{*}{0.947} & \multirow{4}{*}{0.540} \\
\hline & 0.944 & & \\
\hline & 0.904 & & \\
\hline & 0.848 & & \\
\hline \multirow{4}{*}{ Privacy risk } & 0.904 & \multirow{4}{*}{0.949} & \multirow{4}{*}{0.549} \\
\hline & 0.944 & & \\
\hline & 0.904 & & \\
\hline & 0.848 & & \\
\hline \multirow[t]{4}{*}{ Perceived value } & 0.904 & \multirow{4}{*}{0.945} & \multirow{4}{*}{0.543} \\
\hline & 0.944 & & \\
\hline & 0.904 & & \\
\hline & 0.848 & & \\
\hline \multirow[t]{4}{*}{ Trust in technology } & 0.904 & \multirow{4}{*}{0.975} & \multirow{4}{*}{0.865} \\
\hline & 0.944 & & \\
\hline & 0.904 & & \\
\hline & 0.848 & & \\
\hline \multirow[t]{4}{*}{ Social norms } & 0.904 & \multirow{4}{*}{0.971} & \multirow{4}{*}{0.849} \\
\hline & 0.944 & & \\
\hline & 0.904 & & \\
\hline & 0.848 & & \\
\hline \multirow[t]{4}{*}{ Attitude } & 0.904 & \multirow{4}{*}{0.977} & \multirow{4}{*}{0.540} \\
\hline & 0.944 & & \\
\hline & 0.904 & & \\
\hline & 0.848 & & \\
\hline Behavioral intentions & 0.904 & & \\
\hline & 0.944 & 0.981 & 0.600 \\
\hline & 0.904 & 0.901 & 0.000 \\
\hline & 0.848 & & \\
\hline
\end{tabular}


Table 8: Construct reliability: internal consistency and average extracted variance If the AVE cut $=$ off values $>0.5$ and Cronbach alpha $>=0.7$ the construct has achieved construct reliability.

\begin{tabular}{llll} 
Construct & $\begin{array}{l}\text { Average item test } \\
\text { correlation }\end{array}$ & Cronbach alpha & $\begin{array}{l}\text { Average } \\
\text { variance }\end{array}$ \\
\hline Ease of use (EU) & 0.926 & 0.944 & 0.811 \\
Facilitating conditions (FC) & 0.945 & 0.961 & 0.864 \\
Perceived usefulness (PU) & 0.962 & 0.972 & 0.896 \\
Monetary cost (MC) & 0.930 & 0.947 & 0.54 \\
Privacy risk (PR) & 0.931 & 0.949 & 0.549 \\
Perceived value (PV) & 0.926 & 0.945 & 0.543 \\
Trust in technology (TT) & 0.943 & 0.975 & 0.865 \\
Social norms (SN) & 0.934 & 0.971 & 0.849 \\
Attitude (AT) & 0.967 & 0.977 & 0.608 \\
Behavioural intentions (BI) & 0.956 & 0.981 & 0.600 \\
\hline
\end{tabular}

\section{HYPOTHESIS TESTING OF THE STRUCTURAL MODEL}

The assessment of the structural model validity was not sufficient to confirm the structural relationships between constructs; therefore, individual parameter estimates of the proposed model were measured to establish whether the parameter estimates were significant or not. The SEM results in Table 9 were processed using STATA version 13; the standardised estimates were assessed based on the coefficient $\beta$ value and the p-value. According to Hair et al. (2010), a significant parameter estimates entails that the t-value must be greater than 1.96 and the p-value $<=0.05$. Hair et al. (2010) also emphasise that a significant parameter estimate value must be $>0$ for positive relationships and $<0$ for negative relationships whereas the $\mathrm{p}$-value must be $<0.01$ in both instances.

The sections below will discuss in detail how the proposed hypotheses were either accepted or rejected. For ease of presentation of the results, the discussion is organised into categories of hypotheses with similar exogenous constructs.

\subsection{Facilitating conditions $\rightarrow$ Ease of use}

The structural relationship between facilitating conditions and ease of use of smart meters was examined. The results indicate that there was a positive significant relationship between facilitating conditions and ease of use $(\beta=0.867, t=78, p<0.001)$. Thus, H11 was confirmed and accepted. This means that participants agree and confirm that facilitating conditions play an important role in assisting consumers to be able to use smart meters easily. These results concur with previous research (Venkatesh et al., 2012) in that, as individuals are provided with information about how to use smart meter technology, it further enhances their cognitive level. This means that when facilitating conditions increase, the ease of use also increases. 
Table 9: Structural parameter estimates for the smart meter model Significance level: $p<0.05^{*}, p<0.01^{* *}, p<0.000^{* * *}, p>0.1$ Rejected

\begin{tabular}{|c|c|c|c|c|c|}
\hline Hypothesis & Paths & Std. Err & Coefficient $(\beta)$ & $\mathrm{t}$-value & Hypothesis \\
\hline Facilitating conditions $\rightarrow$ Ease of use & $\mathrm{FC} \rightarrow \mathrm{EU}$ & 0.110 & 0.867 & 78.30 & Supported $* * *$ \\
\hline Ease of use $\rightarrow$ Perceived usefulness & $\mathrm{EU} \rightarrow \mathrm{PU}$ & 0.030 & 0.566 & 18.83 & Supported $* * *$ \\
\hline Monetary cost $\rightarrow$ Perceived usefulness & $\mathrm{MC} \rightarrow \mathrm{PU}$ & 0.021 & 0.080 & 3.75 & Supported $* * *$ \\
\hline Trust in technology $\rightarrow$ Perceived usefulness & $\mathrm{TT} \rightarrow \mathrm{PV}$ & 0.031 & 0.362 & 11.57 & Supported $* * *$ \\
\hline Perceived usefulness $\rightarrow$ Perceived value & $\mathrm{PU} \rightarrow \mathrm{PV}$ & 0.022 & 0.687 & 30.02 & Supported $* * *$ \\
\hline Monetary cost $\rightarrow$ Perceived value & $\mathrm{MC} \rightarrow \mathrm{PV}$ & 0.029 & -0.126 & -4.26 & Supported $* * *$ \\
\hline Privacy risk $\rightarrow$ Perceived value & $\mathrm{PR} \rightarrow \mathrm{PV}$ & 0.032 & 0.2276 & 7.07 & Supported $* *$ \\
\hline Ease of use $\rightarrow$ Attitude & $\mathrm{EU} \rightarrow \mathrm{AT}$ & 0.379 & 0.055 & 1.47 & Rejected \\
\hline Perceived usefulness $\rightarrow$ Attitude & $\mathrm{PU} \rightarrow \mathrm{AT}$ & 0.039 & 0.202 & 5.11 & Supported $* * *$ \\
\hline Trust in technology $\rightarrow$ Attitude & $\mathrm{TT} \rightarrow \mathrm{AT}$ & 0.028 & 0.689 & 24.30 & Supported $* * *$ \\
\hline Perceived usefulness $\rightarrow$ Behavioural intention & $\mathrm{PU} \rightarrow \mathrm{BI}$ & 0.028 & 0.0380 & 1.34 & Rejected \\
\hline Perceived value $\rightarrow$ Behavioural intention & $\mathrm{PV} \rightarrow \mathrm{BI}$ & 0.027 & 0.111 & 4.01 & Supported $* * *$ \\
\hline Attitude $\rightarrow$ Behavioural intention & $\mathrm{AT} \rightarrow \mathrm{BI}$ & 0.031 & 0.699 & 22.38 & Supported $* * *$ \\
\hline Facilitating conditions $\rightarrow$ Behavioural intention & $\mathrm{FC} \rightarrow \mathrm{BI}$ & 0.025 & 0.020 & 0.80 & Rejected \\
\hline Trust in technology $\rightarrow$ Behavioural intention & $\mathrm{TT} \rightarrow \mathrm{BI}$ & 0.037 & 0.103 & 2.76 & Supported* \\
\hline Social norm $\rightarrow$ Behavioural intention & $\mathrm{SN} \rightarrow \mathrm{BI}$ & 0.023 & 0.058 & 2.49 & Supported \\
\hline
\end{tabular}

\subsection{Perceived usefulness, privacy risk and monetary cost $\rightarrow$ Perceived value}

The structural relationship between perceived usefulness and perceived value of smart meters was also examined. The results indicated that perceived value was positively and significantly related to perceived usefulness $(\beta=0.688, t=30.02, p<0.001)$, thus confirming hypothesis H10. Benefits that come from the use of smart meter technology can make people value the use of smart meters. The relationship between privacy risk and perceived value of smart meters was also examined and it was found that privacy risk was significantly associated with perceived value $(\beta=0.223, t=7.07, p<0.001)$. Though these results confirmed hypothesis $\mathrm{H}$, the strength of the relationship was weak $(\beta=0.223)$. These results may suggest that, if there are many perceived risks towards the use of smart meters, this will tend to impact negatively on the use of smart meter technology. Furthermore, the relationship between monetary cost and perceived value of smart meters was also examined and found to be significant ( $\beta=$ $-0.127, t=-4.26, p<0.001)$. Hypothesis H6 was confirmed, even though the relationship between the two constructs was negative and weak with a coefficient ( $\beta=-0.127$ ).

The results indicate that if there is high monetary cost towards the use of smart meters, people tend to become negative towards the use of smart meter technology. In summary, the results showed that perceived usefulness $(\beta=0.688)$ was the best predictor for perceived values in comparison to privacy risk $(\beta=0.223)$ and monetary cost $(\beta=-0.127)$, respectively. 


\subsection{Ease of use, monetary cost and trust in technology $\rightarrow$ Perceived usefulness}

The structural relationship between ease of use and perceived usefulness of smart meters was found to be significant $(\beta=0.567, t=18.83, p<0.0001)$, thus verifying hypothesis H4. The structural relationship between monetary cost and perceived usefulness of smart meters was found to be positive and significant $(\beta=0.080, t=3.75, p<0.0001)$, thus verifying hypothesis H9. The results indicated that participants believed that they derived more benefits from the use of smart meters if the cost towards the use of smart meters was less. Furthermore, trust in technology and perceived usefulness were also examined and it was found that trust in technology and perceived usefulness of smart meters was positive and significant ( $\beta=0.362, t=11.57, p<0.0001$ ), thus verifying hypothesis H13. Participants believe that if technology is trustworthy, dependable and reliable it will, in turn, improve the perceived benefit of using smart meters.

In summary, the results showed that ease of use $(\beta=0.567)$ was the best predictor of perceived usefulness in comparison with trust in technology $(\beta=0.362)$ and monetary cost $(\beta=0.080)$. The participants think that the ease of use of smart meters does have an influence on their perceived usefulness of smart meters. The results also concur with the findings of previous studies (Miltgen et al., 2013a; Tan et al., 2012).

\subsection{Perceived usefulness and trust in technology and ease of use $\rightarrow$ Attitude}

The relationship between perceived usefulness and attitude towards smart meters was found to be positive and significant $(\beta=0.202, t=18.83, p<0.0001)$. Consequently, hypothesis H3 was verified and confirmed. These results suggest that, as more benefits are derived from smart meter perceived usefulness, people will eventually change their attitude towards smart meters in managing electricity usage. The relationship between trust in technology and attitude was also examined and was found to be significant $(\beta=0.690, t=24.30, p<0.0001)$, thus hypothesis H14 was verified and accepted. The structural relationship between ease of use and attitude towards smart meters was examined and found not to be significant $(\beta=$ $0.055, t=1.47, p>0.142$ ), thus hypothesis H5 was verified and rejected. This might suggest that participants think that ease of use of smart meters does not have much influence on their attitude toward using smart meters.

In summary, of the three constructs that influence attitude towards smart meters, only trust in technology and perceived usefulness were found to be significant, with trust in technology being the best construct to predict the consumer's attitude towards the use of smart meters. Ease of use was rejected as a construct that influenced attitude. 


\subsection{Perceived value, attitude, social norms, trust in technology and perceived usefulness $\rightarrow$ Behavioural intention}

The relationship between attitude and behavioural intention to accept smart meters was significant $(\beta=0.70, t=22.38, p<0.001)$, thus hypothesis $\mathrm{H} 1$ was verified and accepted. The results suggest that positive attitude towards smart meter technology can be influenced by trust in technology and perceived usefulness which, in turn, have a significant influence on the behavioural intention to use and accept smart meter technology. The relationship between perceived usefulness and behavioural intention to accept smart meter technology was found not to be significant ( $\beta=0.038, t=1.34, p>0.01$ ), thus hypothesis $\mathrm{H} 2$ was verified and rejected. The relationship between perceived value and behavioural intention towards use and acceptance of smart meters was found to be significant $(\beta=0.11, t=4.07, p<0.001)$, thus hypothesis $\mathrm{H} 8$ was verified and accepted. The more people see value in the use of smart meter technology, the more consumers will tend to accept and use smart meter technology.

The relationship between facilitating conditions and behavioural intention was found to be not significant ( $\beta=0.020, t=0.80, p>0.1$ ), thus hypothesis H12 was verified and rejected. The relationship between trust in technology and behavioural intention towards accepting smart meter technology was found to be positive and significant $(\beta=0.103, t=2.76, p<0.05)$, thus hypothesis H15 was verified and accepted. These results suggest that consumers are willing to accept smart meter technology when it is trustworthy, dependable and reliable. The relationship between social norms and behavioural intention to accept smart meters was found to be significant ( $\beta=0.058, t=2.49, p<0.01$ ), thus hypothesis H16 was verified and accepted.

Based on statistical analyses of both the measurement and structural models, documented in Table 5 and Table 10, respectively, this section summarises the structural model relationships that were evaluated as significant for this research study. The significant factors and the relationships between these are illustrated in Figure 2 below.

Table 10: Goodness-of-fit measure for the structural model (Hair et al., 2010; Hair et al., 2017)

\begin{tabular}{llr} 
Name of category & Index & Proposed structural model \\
\hline Chi Square $\left(\Delta X^{2}\right)$ & $\Delta X^{2}$ & 3199.66 \\
\hline Degree of freedom & $D f$ & 963 \\
\hline Probability & $P$ & 0.05 \\
\hline Absolute fit & RMSEA & 0.057 \\
& $90 \%$ confidence interval RMSEA & $0.055-0.06$ \\
& SRMR & 0.06 \\
& Normed $X^{2}$ & 3.32 \\
\hline Incremental fit & CFI & 0.955 \\
& TLI & 0.952 \\
\hline
\end{tabular}




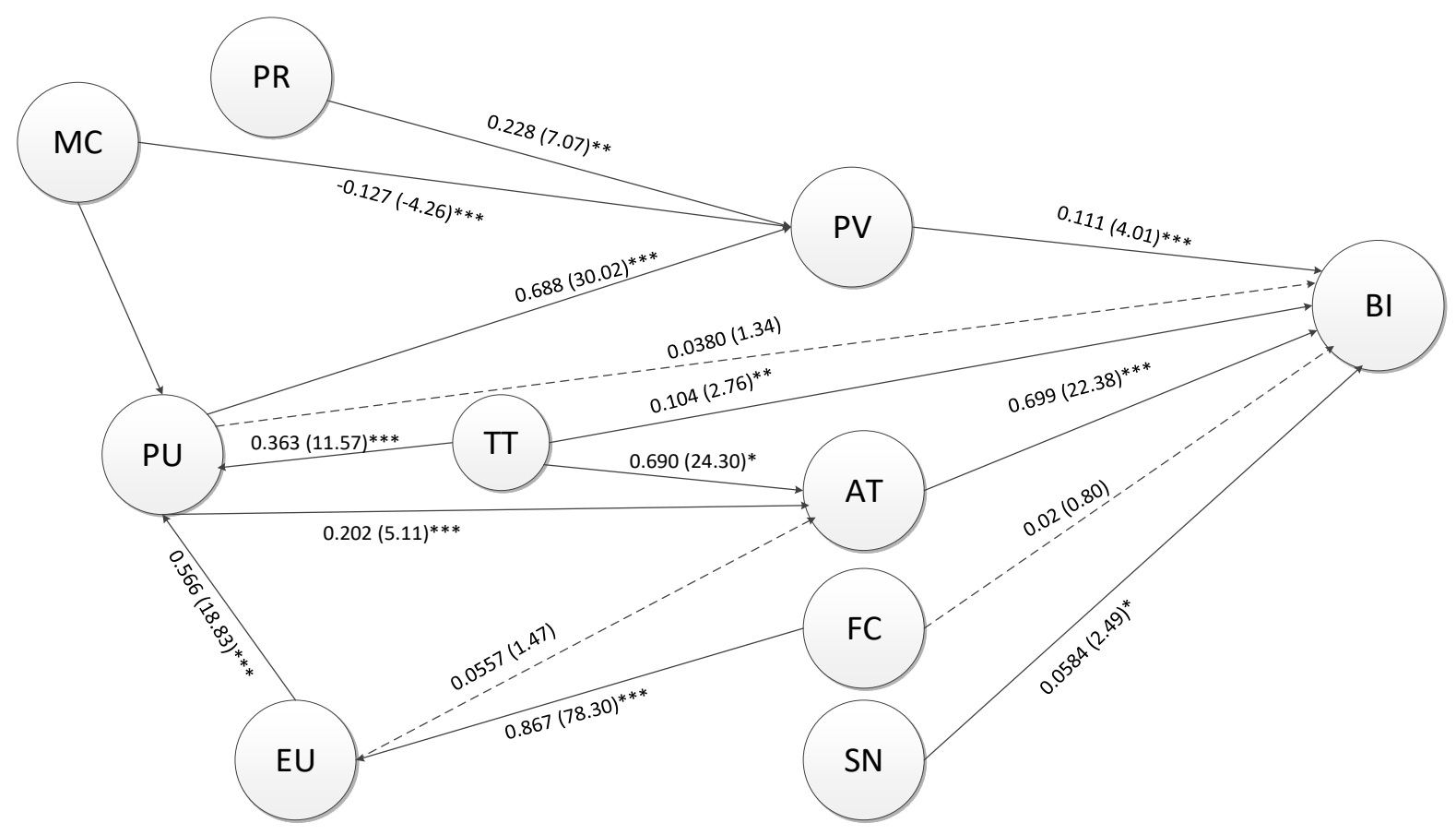

Figure 2: Final research model: proposed structural relationships

Note Numbers in brackets are t-values. The numbers outside the brackets are standardised path coefficients. Dotted arrow lines indicate that the hypothesis is not a significant path $(p>0.1) *$. The solid arrow lines indicate that the hypothesis is significant $(p<0.05) *,(p<0.01) * *$ and $(p<0.001) * * *$

\section{DISCUSSION}

The smart meter adoption and implementation within South Africa is still in its infancy (Smart Energy International, 2019). Hence, the identification of consumer-centric factors is important for the implementation of smart meters in South Africa. In order to better understand the consumer-centric factors involved in the implementation of smart meters, an extensive investigation was conducted into the factors that affect smart meter consumers. A survey was conducted of 768 participants, from both smart meter and non-smart meter users within South Africa. Then, the research identified a myriad of consumer-centric factors that affect the planning for smart meter implementation in South Africa.

From the smart technology acceptance perspective (Ponce-Jara et al., 2017), there has not been a great deal of research in the area; hence, the use of prior work did not assist much in the identification of factors that are important to smart meter technology. The results above show that 13 factors were found to be most important in the implementation of smart meters in South Africa (Table 9). From the findings, utility companies or smart meter service providers must consider these consumer-centric factors for better implementation of smart meters in South Africa. 
As depicted in Table 9 and Figure 2, facilitating conditions were found to be significant when considering ease of use, while perceived ease of use appeared to be important for perceived usefulness from the perspective of the smart meter electricity consumer. These results were in line with other studies (Moon \& Kim, 2001; Teo, 2009; Venkatesh et al., 2012). However, facilitating conditions did not seem to have any direct influence on attitude towards the use and acceptance of smart meter technology. This means that facilitating conditions must be considered in the implementation of smart meters as they can assist the smart meter users in the operation of smart meter technology and, in the process, allow the smart meter users to derive benefits from using smart meters.

Trust in technology, monetary cost and ease of use were found to be significant when considering the perceived usefulness of smart meter technology (Figure 2). This means that, in order to make the smart meter users benefit from using a smart meter, the smart meter needs to be trustworthy, affordable and easy to operate. Otherwise, if the trust in technology, monetary cost and perceived ease of use are not addressed properly, this might have an adverse impact on smart users to even consider using them. In the same light, perceived usefulness, and trust in technology (Orlando \& Vandevelde, 2021) were found to be relevant in enhancing the attitude of potential smart meter consumers towards acceptance and use of smart meter technology.

While Beldad and Hegner (2018) suggest that social norms have impact on ease of use, and although this study found social norms to be significant, Teo (2009) found them to be insignificant as modern consumers are more independent and are not influenced by other people when making important decisions.

This research was conducted with an objective to generalise the findings to other pervasive computing technologies (smart technologies) in future. Evaluating the applicability of the research proposed model to other similar pervasive technologies like smart cities opens another door for future research. As the research was conducted only in South Africa as a country, conducting the same research in multiple countries within Africa can assist in evaluation of the extent to which the factors affecting smart meter technology acceptance and use can be generalised within the African context. Finally, as much as smart meters may bring better consumer management of electricity consumption, the comments from the data collection phase suggest that most participants were not aware of smart meters; hence, there is a need for more awareness campaigns and education to reduce smart meter implementation resistance.

\section{THEORETICAL IMPLICATIONS}

This research study has made several contributions to behavioural studies in a number of ways. Most significant is the contribution to knowledge about the implementation of pervasive computing technologies, such as smart meter acceptance and use in developing countries. This section discusses the theoretical research contributions that can emanate from the research study. 
From the theoretical perspective, this research contributes most importantly to the pervasive technology domain with a rich empirical study that assists technology innovators, utility companies, and policy makers to understand the consumer-centric factors that might affect technology acceptance and use. Since most of the behavioural models and theories were developed a long time ago (such as the TRA, TPB and TAM (Miltgen et al., 2013a)), their application and use in identifying factors that influence smart technology acceptance and use might not be adequate or relevant. The rapid change in technology and user technology interactions has impacted significantly on the way technology is viewed. Hence, the proposed theoretical model developed in this study presents new empirical knowledge that can be refined further in technology acceptance and use studies in the future.

In addition, this study contributes to the model development literature and design. Various theoretical models were identified to assist in developing a competing model for this study. Based on an extensive literature review, the TAM was identified as a fundamental research framework. However, since smart meter technology is a new technological advancement, the TAM was found to be inadequate in helping to understand and identify factors that affect user behaviour to accept and use pervasive technology (Gefen et al., 2003; Wu \& Chen, 2005; T. Zhou, 2011). Therefore, this study contributed to the model development literature by integrating other relevant variables to supplement the TAM inadequacy. In view of smart meter technology, the factors that were found relevant and incorporated into the TAM for the study model development were: privacy risk (PCT), facilitating conditions and monetary cost (UTAUT), social norms (TPB), trust, and perceived value. Consequently, the proposed model output in this study confirms a new contribution to the body of knowledge (Table 2).

Another theoretical contribution that emanated from this study is an enrichment of the African literature about smart meter technology acceptance modelling. From the literature review, it is evident that most smart grid and smart meter roadmaps and studies on technology adoptions acceptance, implementations and post-implementations have been conducted either in the United States of America or in European countries (Rausser et al., 2018; Teo, 2009). Considering that these are developed countries, which have better electricity grid infrastructure, better electricity policies, high-level technical skills, a high sense of environmental consciousness, and high privacy appetite, it must be acknowledged that the situation is different in developing countries like South Africa. It is, therefore, meaningful that the results of this study, which focuses on a South African situation, can contribute or can be used as a reference model in understanding the African smart meter consumer's perspective.

Finally, the results from this research can be adapted by other African countries for the planning of smart meter implementation as opposed to using American or European views, which are far from the African setting.

\section{CONCLUSION}

This study has improved the understanding of consumer-centric factors that must be considered in the implementation and acceptance of smart meters in South Africa. Since there is 
no specific technology acceptance model and theory available to explain in the behavioural intention to accept smart meter technology in general, the research relied on various models postulated. The following models and theories were used in this research: the Technology Acceptance Model, Privacy Calculus Theory, and the Unified Theory of Acceptance and Use of Technology; hence, leading to the complex research model depicted in Figure 1 and Figure 2.

The analysis of the research model allowed important interrelationships amongst consumercentric factors identified and examined in the implementation of smart meters in South Africa. The findings showed that 10 factors, namely perceived ease of use, facilitation conditions, monetary cost, perceived risk, perceived value, trust in technology, social conditions, attitude, and behavioural intentions were identified to be important to smart meter consumers. In the process, it was revealed that perceived value, attitude, trust in technology, and social norms are important factors that directly impact the implementation of smart meters, whilst facilitation conditions, perceived ease of use, perceived usefulness, trust in technology, monetary cost, and privacy risk have indirect impacts on either attitude or perceived value, respectively (Figure 2). These findings were found to concur with the literature review: attitude (Miltgen et al., 2013b), perceived usefulness (Miltgen et al., 2013a), price value (Xiong, 2013), social norms (Beldad \& Hegner, 2018), privacy risk (Xu et al., 2011), trust in technology (Belanche et al., 2012), facilitating conditions (Teo, 2009). Therefore, utility companies, technological innovators and designers should make sure that the smart meters are beneficial and valuable without compromising their easy in usability. On the other hand, policy makers, technology designers and vendors must ensure that smart meters are secure, trustworthy and reliable in providing electricity services to its smart meter consumers, with adequate support.

\section{References}

Agarwal, N., Wang, Z., \& Xu, Y. (2007). Factors affecting 3G adoption: An empirical study. PACIS 2007 Proceedings, 256-277. http://www.pacis-net.org/file/2007/1205.pdf

Ajzen, I. (1985). From intentions to actions: A theory of planned behavior. In J. Kuhl \& J. Beckman (Eds.), Action-control: From cognition to behavior. Springer.

Ajzen, I. (1991). The theory of planned behavior. Organizational Behavior and Human Decision Processes, 50(2), 179-211. https://doi.org/10.1016/0749-5978(91)90020-T

Alharbi, S., \& Drew, S. (2014). Using the technology acceptance model in understanding academics' behavioural intention to use learning management systems. International Journal of Advanced Computer Science and Applications, 5(1), 143-155.

Atkins, P. (2014). Smart meters and smart-enabled prepaid meters project [Department of Economic Development and Tourism, Western Cape Government].

Bamberg, S., Ajzen, I., \& Schmidt, P. (2003). Choice of travel mode in the theory of planned behavior: The roles of past behavior, habit, and reasoned action. Basic and Applied Social Psychology, 25(10), 175-187. https://doi.org/10.1207/S15324834BASP2503_01

Bargh, J. A., \& McKenna, K. Y. A. (2004). The internal and social life. Annual Review of Psychology, 55(1), 573-590. https://doi.org/10.1146/annurev.psych.55.090902.141922 
Barrett, J., Peters, G., Wiedmann, T. O., Scott, K., Lenzen, M., Roelich, K., Quéré, L., \& C. (2013). Consumption-based GHG emission accounting: A UK case study. Climate Policy, 13, 451-570. https://doi.org/10.1080/14693062.2013.788858

Bazilian, M., Welsch, M., Divan, D., Elzinga, D., Strbac, G., Howells, M., Jones, L., Keane, A., Gielen, D., Balijepalli, V. S. K. M., Brew-Hammond, A., \& Yumkella, K. (2013). Smart and just grids for sub-Saharan Africa: Exploring options. Renewable and Sustainable Energy Reviews, 20, 336-352. https://doi.org/10.1016/j.rser.2012.11.004

Belanche, D., Casado, L. V., \& Flavián, C. (2012). Integrating trust and personal values into the Technology Acceptance Model: the case of e-government services adoption. Cuadernos de Economía y Dirección de la Empresa, 15(4), 192-204. https://doi.org/10.1016/j. cede.2012.04.004

Beldad, A., \& Hegner, S. (2018). Expanding the technology acceptance model with the inclusion of trust, social influence, and health valuation to determine the predictors of German users' willingness to continue using a fitness app: A structural equation modeling approach. International Journal of Human-Computer Interaction, 34(9), 882-893. https://doi.org/10.1080/10447318.2017.1403220

Bugden, D., \& Stedman, R. (2018). A synthetic view of acceptance and engagement with smart meters in the United States. Energy Research and Social Science, 47, 137-145. https: //doi.org/10.1016/j.erss.2018.08.025

Camarinha-Matos, L. (2016). Collaborative smart grids - A survey on trends. Renewable and Ssustainable Energy Reviews, 65, 283-294. https://doi.org/10.1016/j.rser.2016.06.093

Chen, C., Fan, Y., \& Farn, C. (2007). Predicting electronic toll collection service adoption: An integration of the technology acceptance model and the theory of planned behavior. Transportation Research Part C: Emerging Technologies, 15(5), 300-311. https://doi.org/ 10.1016/j.trc.2007.04.004

Chen, S., Chen, H., \& Chen, M. (2009). Determinants of satisfaction and continuance intention towards self-service technologies. Industrial Management and Data Systems, 109(9), 1248-1263. https://doi.org/10.1108/02635570911002306

Chen, S., Li, S., \& Li, C. (2011). Recent related research in technology acceptance model: A literature review. Australian Journal of Business and Management Research, 1(9), 124127.

Cheon, J., Lee, S., Crooks, S. M., \& Song, J. (2012). An investigation of mobile learning readiness in higher education based on the theory of planned behavior. Computers and Education, 59(3), 1054-1064. https://doi.org/10.1016/j.compedu.2012.04.015

Cuijpers, C., \& Koops, B. (2013). Smart metering and privacy in Europe: Lessons from the Dutch case. In G. S., L. R., de Hert P., \& P. Y (Eds.), European data protection: Coming of age. https://doi.org/10.1007/978-94-007-5170-5_1

Davis, F. D., Bagozzi, R. P., \& Warshaw, P. R. (1989). User acceptance of computer technology: A comparison of two theoretical models. Management Science, 35(8).

Davis, L. E., Ajzen, I., Saunders, J., \& Williams, T. (2002). The decision of African American students to complete high school: An application of the theory of planned behavior. 
Journal of Educational Psychology, 94(4), 810-819. https://doi.org/10.1037/00220663.94.4.810

Dileep, G. (2019). A survey on smart grid technologies and applications. Renewable Energy, 146, 2589-2625. https://doi.org/10.1016/j.renene.2019.08.092

Dinev, T., Bellotto, M., Hart, P., Russo, V., \& Colautti, C. (2006). Privacy calculus model in e-commerce-A study of Italy and the United States. European Journal of Information Systems, 15(4), 389-402. https://doi.org/10.1057/palgrave.ejis.3000590

Dinev, T., \& Hart, P. (2006). An extended privacy calculus model for e-commerce transactions. Information Systems Research, 17(1), 61-80. https://doi.org/10.1287/isre.1060.0080

Doney, P. M., \& Cannon, J. P. (1997). An examination of the nature of trust in buyer-seller relationships. Journal of Marketing, 61(2), 35-51.

Eberhard, A., Gratwick, K., Morella, E., \& Antmann, P. (2017). Independent power projects in sub-Saharan Africa: Investment trends and policy lessons. Energy Policy, 108, 390-424. https://doi.org/10.1016/j.enpol.2017.05.023

Faruqui, A., Harris, D., \& Hledik, R. (2010). Unlocking the $€ 53$ billion savings from smart meters in the EU: How increasing the adoption of dynamic tariffs could make or break the EU's smart grid investment. Energy Policy, 38(10), 6222-6231. https://doi.org/10. 1016/j.enpol.2010.06.010

Fathema, N., Shannon, D., \& Ross, M. (2015). Expanding the technology acceptance model (TAM) to examine faculty ease of learning management systems (LMSs) in higher education institutions. MERLOT Journal of online learning and teaching, 11(2), 210-232.

Fishbein, M., \& Ajzen, I. (1975). Belief, attitude, intention, and behavior: An introduction to theory and research. Addison-Wesley.

Gefen, D., Karahanna, E., \& Straub, D. W. (2003). Inexperience and experience with online stores: The importance of TAM and trust. IEEE Transactions on Engineering Management, 50(3), 307-321. https://doi.org/10.1109/TEM.2003.817277

Gefen, D., \& Straub, D. W. (2000). The relative importance of perceived ease of use in IS adoption: A study of e-commerce adoption. Journal of the Association for Information Systems, 1(8), 1-30.

Ghalandari, K. (2012). The effect of performance expectancy, effort expectancy, social influence and facilitating conditions on acceptance of e-banking services in Iran: The moderating role of age and gender. Middle-East Journal of Scientific Research, 12(6), 801-807. https://doi.org/10.5829/idosi.mejsr.2012.12.6.2536

Gu, J. C., Lee, S. C., \& Suh, Y. H. (2009). Determinants of behavioral intention to mobile banking. Expert Systems with Applications, 36(9), 11605-11616. https:// doi.org/10. 1016/j.eswa.2009.03.024

Guo, C., Bond, C., \& Narayanan, A. (2015). The adoption of new smart-grid technologies: Incentives, outcomes, and opportunities [Last accessed 10 Dec 2021]. https://doi.org/ 10.1088/1757-899X/199/1/012062

Hair, J. F., Black, W. C., Babin, B. J., \& Anderson, R. E. (2010). Multivariate data analysis (7th). Prentice Hall. 
Hair, J. F., Matthews, L. M., Matthews, R. L., \& Sarstedt, M. (2017). Pls-SEM or CB-SEM: Updated guidelines on which method to use. International Journal of Multivariate Data Analysis, 1(2). https://doi.org/10.1504/ijmda.2017.10008574

Han, L., Chen, W., Zhuang, B., \& Shen, H. (2017). A review on development practice of smart grid technology in China. IOP Conference Series: Materials Science and Engineering, Volume 199. https://doi.org/10.1088/1757-899X/199/1/012062

Hazen, B. T., Overstreet, R. E., \& Wang, Y. (2015). Predicting public bicycle adoption using the technology acceptance model. Sustainability, 7(14558-14573). https://doi.org/10. 3390/su71114558

Holden, R. J., \& Karsh, B. (2010). The technology acceptance model: Its past and its future in health care. Journal of Biomedical Informatics, 43(1), 159-172. https://doi.org/10. 1016/j.jbi.2009.07.002

James, T. L., Warkentin, M., \& Collignon, S. E. (2015). A dual privacy decision model for online social networks. Information and Management, 52(8), 893-908.

Jay, D., Hmielowski, B., D., A., Harvey, G., \& Joo, J. (2019). The social dimensions of smart meters in the United States: Demographics. Energy Research and Social Science, 55, 189197. https://doi.org/10.1016/j.erss.2019.05.003

Joubert, J., \& van Belle, J. (2013). The role of trust and risk in mobile commerce adoption within South Africa. International Journal of Business, Humanities and Technology, 3(2), 27-38. http: / / www. ijbhtnet.com / journals / Vol \% 5C_3 \% 5C_No \% 5C_2\% 5C_ February\%5C_2013/3.pdf

Kaushik, A. K., Agrawal, A. K., \& Rahman, Z. (2015). Tourist behaviour towards self-service hotel technology adoption: Trust and subjective norm as key antecedents. Tourism Management Perspectives, 16, 278-289. https://doi.org/10.1016/j.tmp.2015.09.002

Keith, M. J., Thompson, S. C., Hale, J., Benjamin, P., \& Greer, C. (2013). Information disclosure on mobile device: Re-examining privacy calculus with actual user behavior. Journal of Human Computer Studies, 71(12), 1163-1173. https://doi.org/10.1016/j.ijhcs.2013. 08.016

Kim, Y. J., Chun, J., \& Song, J. (2009). Investigating the role of attitude in technology acceptance from an attitude strength perspective. International Journal of Information Management, 29(1), 67-77. https://doi.org/10.1016/j.ijinfomgt.2008.01.011

Kranz, J., Gallenkamp, J., \& Picot, A. (2010). Exploring the role of control-smart meter acceptance of residential consumers. AMCIS 2010 Proceedings, Paper 315. https://aisel. aisnet.org/amcis2010/315

Kranz, J., Kolbe, L. M., Koo, C., \& Boudreau, M. C. (2015). Smart energy: Where do we stand and where should we go? Electronic markets, 25(1), 7-16. https://doi.org/10.1007/ s12525-015-0180-3

Kranz, J. J., \& Picot, A. (2011). Toward an end-to-end smart grid: Overcoming bottlenecks to facilitate competition and innovation in smart grids. Communications of the National Regulatory Research Institute, 138. 
Krasnova, H., \& Veltri, N. F. (2010). Privacy calculus on social networking sites: Explorative evidence from Germany and USA. 43rd Hawaii International Conference on System Sciences, 1-10., 1-10.

Krejcie, R. V., \& Morgan, D. W. (1970). Determining sample size for research activities. Educational and Psychological Measurement, 30(3), 607-610.

Lai, P. (2017). The literature review of technology adoption models and theories for the novelty technology. Journal of Information Systems and Technology Management, 14(1), 21-38. https://doi.org/10.4301/S1807-17752017000100002

Lee, M. (2009). Factors influencing the adoption of Internet banking: An integration of TAM and TPB with perceived risk and perceived benefit. Electronic Commerce Research and Applications, 8(10), 130-141. https://doi.org/10.1016/j.elerap.2008.11.006

Lu, H., \& Gustafson, H. (1994). An empirical study of perceived usefulness and perceived ease of use on computerized support system use over time. International Journal of Information Management, 14(5), 317-329.

Lynne, G. D., Casey, C. F., Hodges, A., \& Rahmani, M. (1995). Conservation technology adoption decisions and the theory of planned behavior. Journal of Economic Psychology, 16.

Ma, Z., Asmussen, A., \& Jørgensen, B. N. (2018). Industrial consumers' smart grid adoption: Influential factors and participation phases. Energies, 11(1), 182.

Maduku, D. K. (2013). Predicting retail-banking customers' attitude towards Internet banking services in South Africa. South African Business Review, 17(3), 76-100.

Manyika, J., Chui, M., Bughin, J., Dobbs, R., Bisson, P., \& Marrs, A. (2013). Disruptive technologies: Advances that will transform life, business, and the global economy [McKinsey Global Institute]. https://www. mckinsey.com/business-functions/mckinseydigital/our-insights/disruptive-technologies

Martins, C., Oliveira, T., \& Popovič, A. (2014). Understanding the Internet banking adoption: A unified theory of acceptance and use of technology and perceived risk application. International Journal of Information Management, 34, 1-13. https://doi.org/10.1016/j. ijinfomgt.2013.06.002

Mayer, R. C., Davis, J. H., \& Schoorman, F. C. (1995). An integrative model of organizational trust. Academy of Management Review, 20(3), 709-734.

McKenna, E., Richardson, I., \& Thomson, M. (2012). Smart meter data: Balancing consumer privacy concerns with legitimate applications. Energy Policy, 41, 807-814. https://doi. org/10.1016/j.enpol.2011.11.049

McKnight, D., Choudhury, V., \& Kacmar, C. (2002). Developing and validating trust measures for e-commerce: An integrative typology. Information Systems Research, 13(3), 334-359.

Micheni, E. M., Lule, I., \& Muketha, G. M. (2013). Transaction costs and facilitating conditions as indicators of the adoption of mobile money services in Kenya. International Journal of Advanced Trends in Computer Science and Engineering, 2(5), 9-15.

Miltgen, L. C., Popovič, A., \& Oliveira, T. (2013a). Determinants of end-user acceptance of biometrics: Integrating the "Big 3" of technology acceptance with privacy context. Decision Support Systems, 56(1), 103-114. https://doi.org/10.1016/j.dss.2013.05.010 
Miltgen, L. C., Popovič, A., \& Oliveira, T. (2013b). Determinants of end-user acceptance of biometrics: Integrating the "Big 3" of technology acceptance with privacy context. Decision Support Systems, 56(1), 103-114. https://doi.org/10.1016/j.dss.2013.05.010

Moon, J., \& Kim, Y. (2001). Extending the TAM for a World-Wide-Web context. Information and Management, 38(4), 217-230.

Morosan, C., \& DeFranco, A. (2015). It's about time: Revisiting UTAUT2 to examine consumers' intentions to use NFC mobile payments in hotels. International Journal of Hospitality Management, 53(10), 17-29. https://doi.org/10.1016/j.ijhm.2015.11.003

Muller-Seitz, G., Dautzenberg, K., Creusen, U., \& Stromereder, C. (2009). Customer acceptance of RFID technology: Evidence from the German electronic retail sector. Journal of Retailing and Consumer Services, 16(1), 31-39.

Notani, A. (1998). Moderators of perceived behavioral control's predictiveness in the theory of planned behavior: A meta-analysis. Journal of Consumer Psychology, 7(3), 247-271.

Organisation for Economic Co-operation and Development. (2012). Green growth studies: Energy [Last accessed 10 Dec 2021]. https://www.oecd.org/greengrowth/greeningenergy/49157219.pdf

Orlando, D., \& Vandevelde, W. (2021). Smart meters' roll out, solutions in favour of a trust enhancing law in the EU. Journal of Law, Technology and Trust, 2(1). https://doi.org/ 10.19164/jltt.v2i1.1071

Park, S. Y. (2009). An analysis of the technology acceptance model in understanding university students' behavioral intention to use e-learning. Educational Technology and Society, 12(3), 150-162. https://doi.org/10.1007/s00340-009-3513-0

Ponce-Jara, M. A., Ruiz, E., Gil, R., Sancristóbal, E., Pérez-Molina, C., \& Castro, M. (2017). Smart grid: Assessment of the past and present in developed and developing countries. Energy Strategy Reviews, 18, 38-52. https://doi.org/10.1016/j.esr.2017.09.011

Rausser, G., Strielkowski, W., \& Štreimikienè, D. (2018). Smart meters and household electricity consumption: A case study in Ireland. Energy and Environment, 29(1), 131-146. https://doi.org/10.1177/0958305X17741385

Rehman, T., Yates, C. M., McKemey, K., Garforth, C., Cooke, R., Tranter, R. B., Park, J., \& Dorward, P. (2003). Modelling the uptake of new technologies on dairy farms in South West England using the Theory of Reasoned Action and mathematical programming. Agricultural Economics Society conference, Seale Hayne, England.

Roca, J. C., Garcia, J. J., \& de la Vega, J. J. (2009). The importance of perceived trust, security and privacy in online trading systems. Information Management and Computer Security, 17(2), 96-113. https://doi.org/10.1108/09685220910963983

Sánchez-Prieto, J., Olmos-Migueláñez, S., \& García-Peñalvo, F. J. (2015). Informal tools in formal contexts: Development of a model to assess the acceptance of mobile technologies among teachers. Computers in Human Behaviour, 55, 519-528. https://doi.org/10. 1016/j.chb.2015.07.002 
Serenko, A., Bontis, N., \& Detlor, B. (2007). End-user adoption of animated interface agents in everyday work applications. Behaviour and Information Technology, 26(2), 119-132. https://doi.org/10.1080/01449290500260538

Smart Energy International. (2019). The factors behind low smart meter penetration in Africa [Last accessed 10 Dec 2021]. https://www.smart-energy.com/industry-sectors / policy-regulation/the-factors-behind-low-smart-meter-penetration-africa

Srivastava, J., \& Moreland, J. J. (2012). Diffusion of innovations: Communication evolution and influences. The Communication Review, 15(40), 294-312. https://doi.org/10.1080/ 10714421.2012 .728420

Stern, B., Royne, M. B., Stafford, F. T., \& Bienstock, C. C. B. (2008). Consumer acceptance of online auctions: An extension and revision of the TAM. Psychology and Marketing, 25(10), 619-636. https://doi.org/10.1002/mar.20228

Sun, Y., Wang, N., Shen, X., \& Zhang, J. (2015). Computers in human behavior location information disclosure in location-based social network service: Privacy calculus, benefit structure, and gender differences. Computers in Human Behavior, 52, 278-292. https: //doi.org/10.1016/j.chb.2015.06.006

Tan, X., Qin, L., Kim, Y., \& Hsu, J. (2012). Impact of privacy concern in social networking web sites. Internet Research, 22(2), 211-233. https://doi.org/10.1108/10662241211214575

Taneja, A., Vitrano, J., \& Gengo, N. J. (2014). Rationality-based beliefs affecting individual's attitude and intention to use privacy controls on Facebook: An empirical investigation. Computers in Human Behavior, 38, 159-173. https://doi.org/10.1016/j.chb.2014.05. 027

Ten Kate, S., Haverkamp, S., Mahmood, F., \& Feldberg, F. (2010). Social network influences on technology acceptance: A matter of tie strength, centrality and density. 23rd Bled eConference, 18-32.

Teo, T. (2009). The impact of subjective norm and facilitating conditions on pre-service teachers' attitude toward computer use: A structural equation modeling of an extended technology acceptance model. Journal of Educational Computing Research, 40(1), 89-109. https://doi.org/10.2190/EC.40.1.d

Thatcher, J., McKnight, D., Baker, E., Arsal, R. E., \& Roberts, N. H. (n.d.). The role of trust in postadoption IT exploration: An empirical examination of knowledge management systems. IEEE Transactions on Engineering Management, 58, 56-70.

Thomas, T. D., Singh, L., \& Gaffar, K. (2013). The Utility of the UTAUT model in explaining mobile learning adoption in higher education in Guyana. International Journal of Education and Development Using Information and Communication Technology, 9(3), 71-85.

Uitz, I., \& Koitz, R. (2013). Consumer acceptance of location based services in the retail environment. International Journal of Advanced Computer Science and Applications, 4(12).

Vallerand, R. J., Pelletier, L. G., Blais, M. R., Brière, N. M., Senécal, C., \& Vallières, E. F. (1992). The academic motivation scale: A measure of intrinsic, extrinsic, and amotivation in education. Educational and Psychological Measurement, 52, 1003-1019. 
van Ittersum, K., Rogers, W. A., Caine, K. E., O’Brien, M. A., \& Parsons, L. J. (2006). Understanding technology acceptance: Phase 1 - Literature Review and Qualitative Model Development [Technology Report HFATR-0602]. Georgia Institute of Technology, School of Psychology, Human Factors and Aging Laboratory. http://hdl.handle.net/1853/40580

Venkatesh, V., Thong, J. Y. L., \& Xu, X. (2012). Consumer acceptance and use of information technology: Extending the unified theory of acceptance and use of technology. MIS Quarterly, 36(1), 157-178.

Wang, Y., Chen, Q., Hong, T., \& Kang, C. (2019). Review of smart meter data analytics: Applications, methodologies, and challenge. IEEE Transactions on Smart Grid, 10(3), 31253148. https://doi.org/10.1109/TSG.2018.2818167

Willis, T. (2009). An evaluation of the technology acceptance model as a means of understanding online social networking behavior.

World Economic Forum. (2012). Energy for economic growth. Hydrocarbon Processing [Last accessed 10 Dec 2021]. https://www3.weforum.org/docs/WEF_EN_EnergyEconomicGrowth_ IndustryAgenda_2012.pdf

World Economic Forum. (2016). The future of electricity in fast-growing economies attracting investment to provide affordable, accessible and sustainable power [Last accessed 10 Dec 2021]. http://www3.weforum.org/docs/WEF_Future_of_Electricity_2016.pdf

Wu, I. L., \& Chen, J. L. (2005). An extension of trust and TAM model with TPB in the initial adoption of on-line tax: An empirical study. International Journal of Human-Computer Studies, 62(6), 784-808.

Wunderlich, P., Veit, D., \& Sarker, S. (2012). Adoption of information systems in the electricity sector: The issue of smart metering. 18th Americas Conference on Information Systems 2012, AMCIS 2012, 3669-3678.

Xiong, S. (2013). Adoption of mobile banking model based on perceived value and trust. 2013 6th International Conference on Information Management, Innovation Management and Industrial Engineering, 632-635.

Xu, H., Robert, X., Carroll, J. M., Beth, M., Luo, X., Carroll, J. M., \& Rosson, M. B. (2011). The personalization privacy paradox: An exploratory study of decision-making process for location-aware marketing. Decision Support Systems, 51(1), 42-52. https://doi.org/10. 1016/j.dss.2010.11.017

Zamrudi, Z., Karim, S., Faridha, M., Maharani, D., \& Kuraesin, A. (2019). Smart meter adoption: The role of consumer experience in using smart device. Journal of Physics: Conference Series, 1175. https://doi.org/10.1088/1742-6596/1175/1/012038

Zeithaml, A., V. (1988). Consumer perceptions of price, quality and value: A means-end model and synthesis of evidence. Journal of Marketing, 52(3), 2-22. https://doi.org/10.1177/ 002224298805200302

Zhou, S. (2021). The effect of smart meter penetration on dynamic electricity pricing: Evidence from the United States. The Electricity Journal, 34(3). https://doi.org/10.1016/j.tej. 2021.106919 
Zhou, S., \& Brown, M. A. (2017). Smart meter deployment in Europe: A comparative case study on the impacts of national policy schemes. Journal of Cleaner Production, 144, 22-32. https://doi.org/10.1016/j.jclepro.2016.12.031

Zhou, T. (2011). The impact of privacy concern on user adoption of location-based services. Industrial Management \& Data Systems, 111(2), 212-226. https://doi.org/doi:10.1108/ 02635571111115146 


\section{A APPENDIX: DERIVATION OF CONSTRUCT ITEMS}

\section{Table 11: Derivation of construct items}

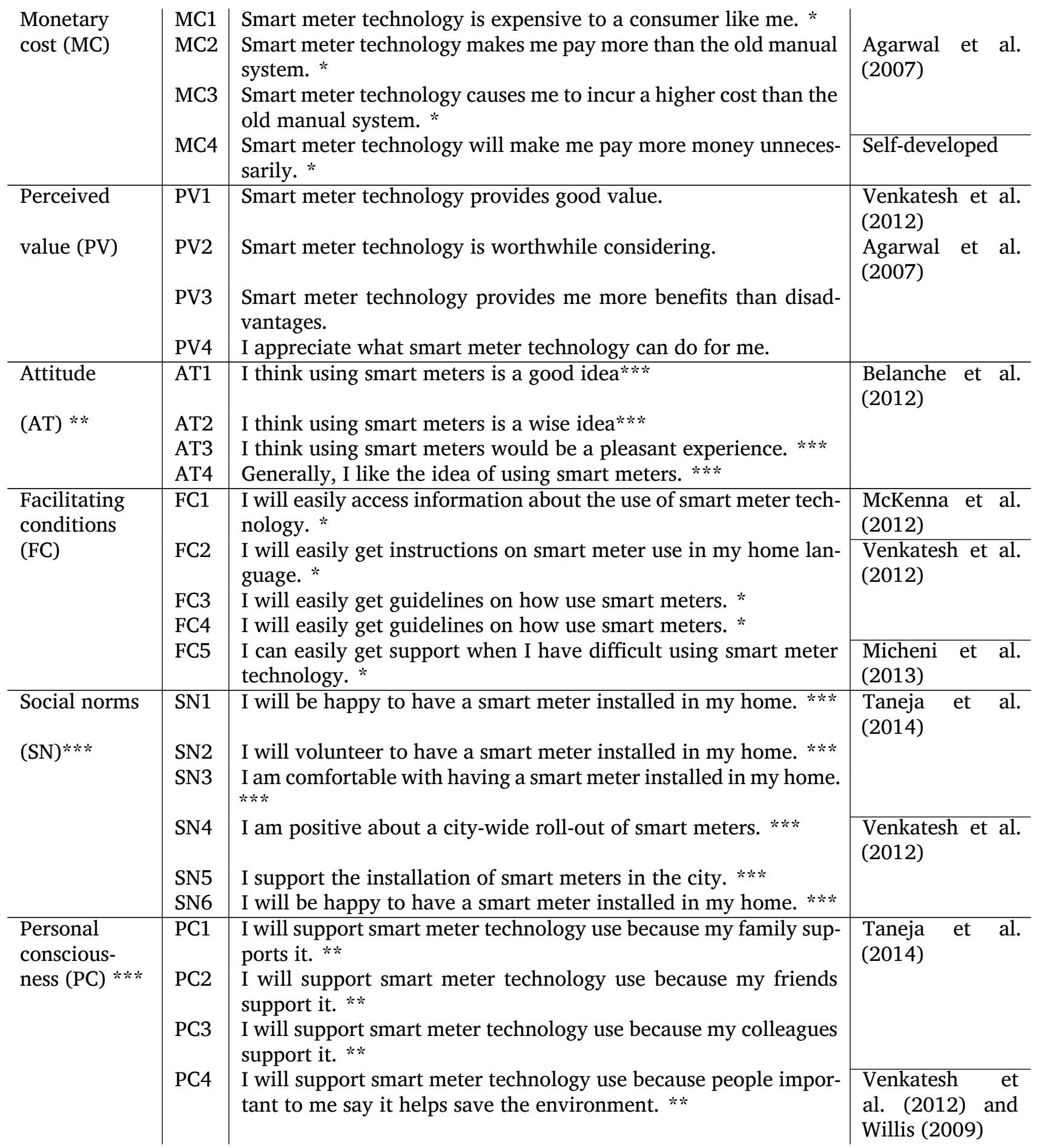




\begin{tabular}{|c|c|c|c|}
\hline & PC6 & $\begin{array}{l}\text { I will support smart meter technology use because people impor- } \\
\text { tant to me think it is the right thing to do. } * * \\
\text { I will support smart meter technology use because I believe it is } \\
\text { the right thing to do. } * *\end{array}$ & \\
\hline $\begin{array}{l}\text { Community } \\
\text { conscious- } \\
\text { ness (CC)** }\end{array}$ & $\begin{array}{l}\mathrm{CC} 1 \\
\mathrm{CC} 2 \\
\mathrm{CC} 3 \\
\mathrm{CC} 4 \\
\mathrm{CC} 5\end{array}$ & $\begin{array}{l}\text { I will support the use of smart meter technology because my com- } \\
\text { munity thinks it is good to manage and distribute electricity. } * * \\
\text { I will support the use of smart meter technology because my com- } \\
\text { munity thinks it prevents electricity theft. ** } \\
\text { I will support the use of smart meter technology if my political } \\
\text { affiliate party supports it. ** } \\
\text { I will support the use of smart meter technology if my community } \\
\text { thinks it saves electricity. ** } \\
\text { Overall, I will support the use of smart meter technology if my } \\
\text { community thinks it saves the environment. ** }\end{array}$ & Willis (2009) \\
\hline \multirow{2}{*}{$\begin{array}{l}\text { Behavioural } \\
\text { intention to } \\
\text { use smart } \\
\text { meters (BI) }\end{array}$} & $\begin{array}{l}\mathrm{BI} 1 \\
\mathrm{BI} 2\end{array}$ & $\begin{array}{l}\text { I will be happy to have smart meter installed at my home. } \\
\text { I am favourable towards having a smart meter installed in my } \\
\text { home. }\end{array}$ & Xu et al. (2011) \\
\hline & $\begin{array}{l}\text { BI3 } \\
\text { BI4 } \\
\text { BI5 } \\
\text { BI6 } \\
\text { BI7 }\end{array}$ & $\begin{array}{l}\text { I will volunteer to have a smart meter installed in my home. } \\
\text { I am comfortable to have a smart meter installed in my home. } \\
\text { I plan to have smart meter installed in my home }{ }^{* *} \\
\text { I support the installation of smart meters in the city. } \\
\text { I am positive about a city-wide roll-out of smart meters. }\end{array}$ & $\begin{array}{l}\text { Venkatesh et al. } \\
(2012) \\
\text { Kaushik et al. } \\
(2015)\end{array}$ \\
\hline
\end{tabular}




\section{B APPENDIX: FINAL CONSTRUCT ITEMS}

\section{Table 12: Final construct items}

\begin{tabular}{|c|c|c|}
\hline $\begin{array}{l}\text { Trust in } \\
\text { technology (TT) }\end{array}$ & $\begin{array}{l}\text { TT1 } \\
\text { TT2 } \\
\text { TT3 } \\
\text { TT4 } \\
\text { TT5 } \\
\text { TT6 }\end{array}$ & $\begin{array}{l}\text { Smart meter technology is trustworthy. } \\
\text { Smart meter technology is dependable. } \\
\text { Smart meter technology is credible in managing electricity demand \& supply. } \\
\text { Smart meter technology has a good reputation in the electricity industry. } \\
\text { Smart meter technology improves reliable electricity supply. } \\
\text { Smart meter technology records electricity billing information accurately. }\end{array}$ \\
\hline $\begin{array}{l}\text { Perceived } \\
\text { usefulness (PU) }\end{array}$ & $\begin{array}{l}\text { PU1 } \\
\text { PU2 } \\
\text { PU3 } \\
\text { PU4 }\end{array}$ & $\begin{array}{l}\text { Smart meter makes it easier for me to monitor \& adjust my electricity usage. } \\
\text { Smart meter makes it easier to manage electricity usage. } \\
\text { Smart meter makes it easy for me to get timely billing information. } \\
\text { Smart meter makes it easier for me to use electricity efficiently. }\end{array}$ \\
\hline $\begin{array}{l}\text { Perceived ease } \\
\text { of use (EU) }\end{array}$ & $\begin{array}{l}\text { EU1 } \\
\text { EU2 } \\
\text { EU3 } \\
\text { EU4 }\end{array}$ & $\begin{array}{l}\text { I will find it easy to use a smart meter. } \\
\text { I will find it easy to learn how to operate the smart meter. } \\
\text { I will find it easy to get the smart meter to do what I want it to do. } \\
\text { It will not require any mental effort to use the smart meter. }\end{array}$ \\
\hline $\begin{array}{l}\text { Privacy risk } \\
\text { (PR) }\end{array}$ & $\begin{array}{l}\text { PR1 } \\
\text { PR2 } \\
\text { PR3 } \\
\text { PR4 }\end{array}$ & $\begin{array}{l}\text { I think smart meter technology makes it easier for my personal data to be } \\
\text { misused for market research and advertising without my knowledge. } \\
\text { I think smart meter technology allows easier access to my personal data } \\
\text { without my knowledge. } \\
\text { I think smart meter technology makes me vulnerable to criminals. } \\
\text { I think smart meter technology put my privacy at risk. }\end{array}$ \\
\hline $\begin{array}{l}\text { Monetary } \\
\text { cost (MC) }\end{array}$ & $\begin{array}{l}\text { MC1 } \\
\text { MC2 } \\
\text { MC3 } \\
\text { MC4 }\end{array}$ & $\begin{array}{l}\text { Smart meter technology will make me pay more money unnecessarily. } \\
\text { Smart meter technology will make me pay more than the old manual system. } \\
\text { Smart meter technology will cause me to incur a higher cost than the old } \\
\text { manual system. } \\
\text { Smart meter technology will be expensive to a consumer like me. }\end{array}$ \\
\hline $\begin{array}{l}\text { Perceived } \\
\text { value (PV) }\end{array}$ & $\begin{array}{l}\text { PV1 } \\
\text { PV2 } \\
\text { PV3 } \\
\text { PV4 }\end{array}$ & $\begin{array}{l}\text { Smart meter technology provides good value. } \\
\text { Smart meter technology is worthwhile considering. } \\
\text { Smart meter technology provides me more benefits than disadvantages. } \\
\text { I appreciate what smart meter technology can do for me. }\end{array}$ \\
\hline $\begin{array}{l}\text { Attitude } \\
\text { (AT) }\end{array}$ & $\begin{array}{l}\text { AT1 } \\
\text { AT2 } \\
\text { AT3 } \\
\text { AT4 }\end{array}$ & $\begin{array}{l}\text { I think using smart meters is a good idea. } \\
\text { I think using smart meters is a wise idea. } \\
\text { I think using smart meters would be a pleasant experience. } \\
\text { Generally, I like the idea of using smart meters. }\end{array}$ \\
\hline $\begin{array}{l}\text { Facilitating } \\
\text { conditions } \\
\text { (FC) }\end{array}$ & $\begin{array}{l}\text { FC1 } \\
\text { FC2 } \\
\text { FC3 } \\
\text { FC4 } \\
\text { FC5 }\end{array}$ & $\begin{array}{l}\text { Gaining access to information about the use of smart meters will be easy. } \\
\text { Obtaining instructions for smart meter use will be easy. } \\
\text { Obtaining guidelines on how to use smart meters will be easy. } \\
\text { I can easily get support when I experience difficulties using smart meters. } \\
\text { Gaining access to information about the use of smart meters will be easy. }\end{array}$ \\
\hline $\begin{array}{l}\text { Social norms } \\
\text { (SN) }\end{array}$ & $\begin{array}{l}\text { SN1 } \\
\text { SN2 } \\
\text { SN3 } \\
\text { SN4 } \\
\text { SN5 } \\
\text { SN6 }\end{array}$ & $\begin{array}{l}\text { I will be happy to have a smart meter installed in my home. } \\
\text { I will volunteer to have a smart meter installed in my home. } \\
\text { I am comfortable with having a smart meter installed in my home. } \\
\text { I am positive about a city-wide roll-out of smart meters. } \\
\text { I support the installation of smart meters in the city. } \\
\text { I will be happy to have a smart meter installed in my home. }\end{array}$ \\
\hline & BI1 & I will be happy to have smart meter installed in my home. \\
\hline
\end{tabular}




\begin{tabular}{l|l|l} 
& BI2 & I intent to have a smart meter installed in my home. \\
Behavioral & BI3 & I will volunteer to have a smart meter installed at my home. \\
intention (BI) & BI4 & I am comfortable to have a smart meter installed in my home. \\
& BI5 & I am positive about a city-wide roll-out of smart meters. \\
& BI6 & I support the installation of smart meters in the city.
\end{tabular}

